\title{
Income Perception, Information, and Progressive Taxation: Evidence from a Survey Experiment
}

Acknowledgments: We thank Aina Gallego, Jona Linde, Karen Long Jusko, Peter John Loewen, John Sides, three anonymous reviewers, and the editor, for very helpful comments on this paper. Previous versions of the paper were presented at the annual meetings of the Midwest Political Science Association, European Political Science Association, Council for European Studies, and American Political Science Association. Fernández-Albertos acknowledges financial support from the Spanish Ministry for the Economy and Competitiveness, project reference no. CSO2013-48451-R. We also thank Modesto Escobar Mercado and the University of Salamanca for fielding the additional survey and providing supplemental data. This latter survey was made possible by financial support from the 2008-2011 National Program Plan for Scientific Research, Development and Technological Innovation (I+ D+I) of the Spanish Ministry for the Economy and Competitiveness (project reference no. CSO2011-27005). 


\begin{abstract}
Are individuals accurately informed about their place in the income distribution? Despite the importance of accurate information about one's placement in the income distribution for many models of redistribution, this assumption remains untested. We present survey data and an embedded experiment where we inform some individuals their true place in the income distribution. We find that individuals have considerable error regarding their self-placement in the income distribution. Revealing to individuals their true placement affects progressivity preferences for individuals who learn they are poor, and for individuals whose prior is that they are poor. These results have implications for information assumptions of redistribution models of comparative political economy, extant models of citizen information and redistribution preferences, and demonstrate the importance of studying views towards tax progressivity preferences, an understudied dimension of redistribution preferences.
\end{abstract}




\section{Introduction}

Are individuals accurately informed about their location in their national income distribution? What is the impact of individuals' subjective income placement (where individuals believe they are in a country's income distribution), as opposed to objective income placement (where individuals actually are located in the income distribution), on preferences over basic policy issues of progressive taxation? To what extent does learning about one's actual placement in the income distribution affect such preferences?

Despite the recent proliferation of research on preferences over redistribution, surprisingly few studies test the assumption that individuals' views of their placement in the income distribution match their actual placement in that distribution. These assumptions are components of some canonical political economy models of preferences over tax rates and transfers. ${ }^{1}$ Such assumptions are also normatively relevant as individuals may be misinformed about their true position in the income distribution; were they properly informed, their preferences over tax rates and redistribution may change.

The emerging literature on redistribution preferences also suffers from another major lacuna, as few studies explain variation in preferences over tax rates and progressivity of tax systems, an obviously crucial component of redistribution policies. The absence of much data on specific tax preferences is striking given that such preferences are implicitly assumed in views towards overall redistribution. Citizen views of the amount of overall redistribution that they prefer can be partially conditioned by their preferred amount of progressive taxation. Further, issues of tax rates or the perceived fairness of the overall tax system are often salient political issues in advanced democracies (recent rhetoric regarding the economic gains to the top one

\footnotetext{
${ }^{1}$ Romer (1975) ; Meltzer and Richard (1981)
} 
percent of the income distribution in the United States and other advanced industrialized democracies and the proposals to increase top marginal tax rates are related examples of how tax schedules are becoming politically salient). ${ }^{2}$ The relative paucity of political behavior studies on preferred tax rates contrasts with the voluminous amount of research that measures views towards redistribution generally. This research either examines general attitudes towards redistribution (such as whether the government should reduce differences between the rich and poor), or views about various decomposition of types of redistribution (such as assistance for the unemployed and support for other types of transfers in different policy categories). ${ }^{3}$ While more sophisticated versions of these preference questions remind citizens of tax increases needed to pay for such redistribution, careful analysis of the determinants of the variation in preferred degree of progressivity is lacking.

In this study we address these two deficiencies by presenting findings from new survey data from a nationally representative population in an advanced industrialized country (Spain) with an embedded information experiment. We use survey data to test the assumption that people know their location in the income distribution, by asking individuals to give their perceived placement in the income distribution. We then inform a randomly selected subset their true place in the income distribution, and assess the impact of such information on tax progressivity preferences. We first find that individuals are not necessarily well-informed about their placement in the income distribution, contra the assumptions of existing models. Citizens tend to believe that they belong to middle income groups, whether they are in reality richer or poorer

\footnotetext{
${ }^{2}$ The recent influential work by Piketty also highlights the importance of tax policy preferences and inequality. Piketty (2014)

${ }^{3}$ For examples of the growing literature on attitudes towards redistribution, and in particular studies that decompose redistribution into specific types of transfers or policies, see Gingrich and Ansell (2012); Iversen and Soskice (2001); Rehm (2009); Rehm (2011); Margalit (2013); Rueda (2005); Rehm, Hacker, and Schlesinger (2012).
} 
than the median income. Our main experimental findings are that informing individuals of their true placement in the income distribution increases support for tax progressivity, but mainly for individuals who learn they are in the bottom quintile of the distribution, and for those who believe they are poor and learn that they are poorer than they thought. In contrast, we find little information effects for those with incomes greater than the median and for those who learn that are richer than what they thought. The results contribute to our understanding of key informational assumptions of basic redistribution models and demonstrate the impact of information on policy preferences.

The paper proceeds as follows. Section one describes the relevant literatures we build upon. Section two presents a basic theoretical discussion and hypotheses. Section three presents the research design and discusses the survey instrument in detail. Section four presents the data from the control group and the experimental results. Section five concludes.

\section{Section 1. Background literature}

Our study builds on two developing literatures in comparative political economy and political behavior regarding redistribution preferences. The first is a growing body of work that tries to measure the degree of misinformation citizens have about issues relevant to redistribution, and how such misinformation affects preferences. Recent findings document how individuals are misinformed about various facts that are theorized to influence redistribution preferences, though most of these studies focus on US citizens and misinformation about specific policies. ${ }^{4}$ For example, Americans relative to Europeans are more likely to underestimate the

\footnotetext{
${ }^{4}$ A large debate in the US behavior literature examines how informed Americans are on various aspects of public policy and whether this ignorance matters. A research tradition in the vein of Kulkinski et al. finds that misinformation is rampant and that such misinformation has implications for citizen welfare; a contrasting set of studies by Page and Shapiro finds general high levels of citizen knowledge (Kuklinski, Quirk, Jerit, Schwieder, \& Rich, 2000; Page \& Shapiro, 2010). For other studies exploring the degree of political knowledge in the United States see Neuman (1992); Carpini and Keeter (1996). Recent studies that debate the true level of political knowledge include Luskin and Bullock (2011); Boudreau et al. (2011); Prior and Lupia (2008). In this study we
} 
income gap between the rich and poor in their respective countries, ${ }^{5}$ are less aware of the extent of inequality at the top of the income distribution, and are less concerned about reducing differentials at the bottom of the distribution. ${ }^{6}$ Other studies find that most US citizens are overly optimistic in estimating their future economic standing, and a raft of evidence cites American over-estimation of the degree of income mobility. ${ }^{7}$

Given the debate over how informed citizens are on relevant redistribution issues, some studies assess the relationship between relevant information and policy preferences. The results of the relationship between information and preferences in the US context is mixed. Using observational data regarding views on the US tax cuts of 2001 and 2003, Bartels finds that political information does not increase opposition to such policies, even from citizens who would not necessarily benefit from such policies. ${ }^{8}$ Experimental studies find some effects of information on tax and social policy preferences and awareness. For example, Duflo and Saez and Chetty and Saez ${ }^{9}$ show that information about retirement plans and the tax code can affect views and participation in such plans. ${ }^{10}$ On the issue of the US estate tax, Sides finds that information about the extent of the tax affects support for it. ${ }^{11}$ However, many of these experiments are limited to a US specific setting. In the study most relevant to our design, Cruces,

focus only on information that is relevant to the domain of redistribution and taxation, and use a non-American sample.

${ }^{5}$ Osberg and Smeeding (2006); Norton and Ariely (2011)

${ }^{6}$ For an alternative view on estimates of error in inequality among US citizens, see McCall and Chin (2013).

${ }^{7}$ See Neckerman and Torche (2007) and DiPrete (2007).

${ }^{8}$ Bartels (2005)

${ }^{9}$ Duflo and Saez (2003) and Chetty and Saez (2013)

${ }^{10}$ Chetty and Saez provide an overview of US based evidence regarding Earned Income Tax Credit (EITC), retirement plans, and other specific policies demonstrating much ignorance over benefits of these policies (Chetty \& Saez, 2013). Kuziemko, Norton, et al. also find using survey experiments that respondents update their views about income inequality when presented with information about the current distribution of income; they conclude that information about true inequality distributions can reduce nearly forty percent of the disparity in perceptions of inequality (2013). However, McCall and Chin find that knowledge about inequality does not necessarily correlate with desiring to reduce it through redistribution (McCall \& Chin, 2013).

11 Sides (2011) 
Truglia et al. use a survey experiment fielded in Buenos Aires, Argentina, to show that informing respondents of their actual relative position increases support for government-provided goods for the poor. ${ }^{12}$ We build upon this element of their design, but sample from the national population in an advanced industrialized democracy and focus on progressive taxation preferences; we discuss later in the theoretical and design section some departures from their study.

Despite these advances in the study of citizen misinformation regarding issues of redistribution and inequality in advanced democracies, few studies measure a crucial theorized determinant of redistribution preferences: the knowledge of citizens regarding their relative income position in the country's income distribution. This gap is surprising given that accurate self-placement is a basic component in much of the theoretical literature on citizen preferences for redistribution. In simple models with straightforward redistributive preferences where individuals prefer to tax incomes above a threshold to fund transfers to incomes below another threshold, individuals with inaccurate information about their position vis-à-vis these thresholds will have wrong views of their net benefits from a redistributive policy. Accurate information regarding self-placement should therefore affect whether citizens support redistribution and the amount of taxes and transfers preferred. ${ }^{13}$ While there is a general literature on the lack of political information of individuals and citizen innumeracy, there is less research on individual self-perceptions of location in human distributions (even in domains outside of political

\footnotetext{
${ }^{12}$ Cruces et al. (2013)

${ }^{13}$ Cruces et al. (2013) provide a straightforward formal intuition, discussed below, for one reason why relative income perception can affect tax and transfer preferences. They focus on the relevance of inaccurate inferences based on improper generalization of the income of one's reference group. As they write, "With access to the correct information about their actual place in the income distribution, self-interest would make these individuals change their attitude and favor, rather than oppose, the redistributive policy (102).”
} 
economy). ${ }^{14}$ With the exception of the innovative study by Cruces et al. (henceforth CPT) ${ }^{15}$ no study assesses how informing individuals in an advanced industrialized democracy of their true relative income position affects tax preferences. ${ }^{16}$

This study also builds upon a second branch of literature that aims to explain preferences regarding the progressivity of the tax system, an area where there are far fewer empirical studies relative to the large literature on preferences for redistribution and transfers generally (see the examples cited above in note 3). A vast theoretical public economics economic literature discusses when tax progressivity would be a political equilibrium, but few studies measure individual preferences for degrees of progressivity. In one class of standard redistribution models, poorer voters prefer higher progressivity and redistribution. ${ }^{17}$ Other models by contrast argue that the extreme poor and rich voters prefer regressivity due to assumptions about the labor-enhancing effect of regressive taxation, as lower tax rates on the rich are theorized to induce the rich to earn more; thus they eventually pay more taxes that can then be redistributed to the poor. By these models it is the middle class that prefers progressivity. ${ }^{18}$ Our study is not about arbitrating among these competing models (see Hindriks 2001, Marhuenda and Ortuño-

\footnotetext{
${ }^{14}$ Hereafter we use the expressions "perceived decile," "perceived income," "perceived relative income,” and "subjective income perception" interchangeably. Regarding citizen inaccuracy about self-placement in a distribution, some studies distinguish between subjective and objective probabilities and perceived versus actual survival rates, such as in Manski (2004) and Hurd (2009). Many studies examine errors of individuals regarding both objective and relative placement of their own body mass indices (BMI) or weights. See Kuchler and Variyam (2003); Maximova et al. (2008); Truesdale and Stevens (2008).

${ }^{15}$ Cruces, Truglia, and Tetaz (2013)

${ }^{16}$ Other information properties of these models have been critiqued. Knowledge over subjective income placement is one of many informational assumptions in many redistribution models; other relevant assumptions include knowledge over the importance of effort in income determination (Bénabou \& Tirole, 2006), evaluation of prospects of economic mobility (A. Alesina \& La Ferrara, 2005; Bénabou \& Ok, 2001), and ability to make correct statistical inferences of their distribution based on exposure to relevant reference groups (Cruces, et al. 2013). These informational assumptions are distinct from other relevant attitudes towards redistribution, such as view towards fairness or beliefs about the cause of poverty (Alberto Alesina \& Angeletos, 2005)

${ }^{17}$ (Roemer, 1999)

${ }^{18}$ (Hindriks, 2001). By this logic progressive taxes are highest when the distribution of abilities is tightly concentrated around the middle.
} 
Ortin 1995, Roemer 1999, for different derivations of the about the equilibrium degree of tax progressivity ${ }^{19}$, but rather about measuring the preferences for and the correlates of basic levels of progressivity and the impact of information on such preferences. ${ }^{20}$

The empirical literature on preferences for tax progressivity is limited, compared to the proliferation of studies cited above on various forms of redistribution. In the United States, McCall provides evidence on the correlation between concerns about inequality and preferences for progressivity. ${ }^{21}$ Other studies focus on framing effects; Roberts, Hite, et al., find that US subjects are often confused about the difference between flat and progressive taxes, ${ }^{22}$ while Slemrod finds using US data that citizens are mistaken about the degree of progressivity in the US system. ${ }^{23}$ Reimers also finds framing effects in the United Kingdom regarding preferences for progressive taxation; participants favored progressivity more when a tax was described as a percentage rather than amount. ${ }^{24}$ Heinemann and Hennighausen find that individual attitudes toward progressive taxation in Germany are partially driven by fairness considerations. ${ }^{25}$ These

\footnotetext{
${ }^{19}$ Marhuenda and Ortuño-Ortin (1995) argue that progressive taxation is a political equilibrium, and Roemer (1999) argues that this equilibrium is the result of factional competition within a left and right-wing political party. By contrast, Hindriks (2001) argues both progressive and regressive systems can exist in equilibrium; De Donder and Hindriks (2003) argue that progressive taxation is only likely in countries where there are more middle-income voters; Snyder and Kramer (1988) also posit that progressive taxation is a result of middle-class voters choosing to reduce tax burdens on themselves. Scheve and Stasavage present a more historical view and argue that highly progressive taxation policies are the result of early twentieth war-time participation and pressure from domestic publics to equalize war-time participation burdens (in part by imposing higher top marginal tax rates) (2010). ${ }^{20}$ Beramendi and Rehm (Forthcoming) argue that the progressivity of the tax-benefit system itself can affect preferences, in terms of the predictive power of income on preferences for redistribution. In their theoretical model, individual attitudes are related to expected net benefits, which are determined by what individuals receive (characterized by the probability of receiving a transfer and the transfer's structure) and what individuals contribute to the system in the form of taxes. The level of progressivity determines the distribution of both, thereby accounting for cross-national variation in the distribution of preferences about the welfare state; they conclude that the more progressive the fiscal system is, the greater the predictive power of income on redistribution preferences. In this study we focus on the determinants of another variable, the baseline preferences for progressivity.

${ }^{21}$ McCall and McCall and Kenworthy examine the relationship between progressivity attitudes and redistribution in the US context (McCall, 2013; McCall \& Kenworthy, 2009).

${ }^{22}$ Roberts, Hite, and Bradley (1994)

${ }^{23}$ Slemrod (2006)

${ }^{24}$ Reimers (2009)

${ }^{25}$ Heinemann and Hennighausen (2010)
} 
studies however also do not test the assumption about accurate individual self-placement in the income distribution.

\section{Section 2. Theoretical discussion and hypotheses}

We address these two main omissions by first turning to a specific theoretical discussion of the effect of relative income misperception and correcting such misperception on progressivity preferences. Because our study builds upon some of the theoretical intuition described by CPT, we borrow some of their terminology and notation in this section, although we also extend and specify some other sensible hypotheses that go beyond their theoretical discussion and empirical design. Throughout the text we use their terminology of error in income perception as "bias,” and the terms "bias correction" and our terminology of "information to correct misperceptions" interchangeably (for example, individuals with “no bias” are correct in their relative income selfplacement). We first simply specify how perceived income and amount of bias in income perception should affect preferences for tax progressivity. ${ }^{26}$ Given that most extant public economics models assume no bias in income perception, and therefore that perceived relative income and actual income are equivalent, perceived income should be negatively correlated with progressivity to finance transfers, as higher income individuals would face both higher effective and marginal tax rates. ${ }^{27}$

\footnotetext{
${ }^{26}$ This discussion draws on notation used in CPT. See pages 107-08 for details on how bias correction affects views on redistribution, via a simple mapping function from perceived rank to views on redistribution. Alternative models explicitly take into account citizen preferences for inequity aversion to explain tax preferences (Fehr \& Schmidt, 1999; Lu \& Scheve, 2014; Michelbach, Scott, Matland, \& Bornstein, 2003; Scott, Matland, Michelbach, \& Bornstein, 2001). Michebach et al. (2003) in particular find that in experimental games where citizens can choose income distributions, many favor Rawlsian min-max strategies. In terms of the mapping function described by CPT, models that assume some inequity aversion (particularly among rich individuals) would have a non-monotonic functional form. Our experimental design does not permit us to distinguish among these different classes of models, but in the results and in the discussion section we suggest how some of the experimental findings could be viewed as consistent with this alternative class of models.

${ }^{27}$ See discussion for example in Klor (2003).
} 
How might information about one's true place in the income distribution affect preferences for progressivity? As CPT describe, any mapping function of perceived income to redistribution preferences means that above a certain income threshold, the individual prefers a certain tax scheme; consistent with many public economics models, higher incomes imply more opposition to progressive tax rates. Learning that one is relatively richer or poorer, following standard self-interested economic voting models, means that those informed that they are richer (poorer) would be more opposed (favorable) to progressive taxation. CPT specify a simple algebraic expression for an "update function,” where bias correction (via experimental intervention) affects redistribution policy preferences through changes in perceived income. We similarly argue that this update function should lead to changes in views towards progressivity.

We first pose a set of basic hypotheses that specify the effect of perceived relative income on tax progressivity. These hypotheses are largely based on the preceding discussion about predictions about the effect of actual income on such preferences, as individual-level models often presume full information about one’s relative income position. Drawing on basic models discussed above of support for tax progressivity and the assumptions of models with full information, we start by positing the following simple null hypotheses:

H1a: Objective income is positively correlated with subjective income placement. H1b: Subjective income placement is negatively correlated with support for tax progressivity.

We now turn to discussion of hypotheses about the effect that information correcting misperceptions would have on tax progressivity. How might "bias correction” or accurate information affect such views? We specify four categories of hypotheses in which bias correction could matter. These categories of course are not exhaustive, but they capture sensible 
relationships between information provision and tax preferences. Our between-subjects design allows us to assess different ways in which this information affects preferences (as we wish to compare individuals who might equivalently misinformed, to isolate the impact of bias correction). These different hypotheses predict the impact of: (1) the simple direction of bias, (2) the respondent's prior belief and direction of bias, (3) the magnitude of bias correction, and (4) the final income position learned. It should be noted that these hypotheses can only be tested in a between-subjects design: that is, we can compare individuals who are equally biased or have the same misperceptions, and observe how random assignment of bias-correcting information affects preferences.

Our first theoretical intuition follows from CPT's focus on the simple role of the direction of bias correction. As they write, and what follows from the bulk of their analysis, "the most natural choice is to estimate the effect of the informational treatment for three groups: those with a positive bias, those with a negative bias, and those without any bias," 28 and they hypothesize (and find) that individuals who have their "positive” bias corrected (that is, they learn via treatment that they are poorer) become more pro-redistribution. Learning that one is relatively richer or poorer than one thought, relative to those who are similarly biased but do not learn, should lead to corresponding differences in support for progressivity. Therefore we specify:

H2a: Individuals who learn they are relatively poorer than they thought should be more supportive of progressive taxation relative to individuals who are equally misinformed, but who do not learn their true position in the income distribution.

\footnotetext{
${ }^{28}$ Cruces et al. (2013), pp. 108.
} 
H2b: Individuals who learn they are relatively richer than they thought should be less supportive of progressive taxation relative to individuals who are equally misinformed, but who do not learn their true position in the income distribution.

However, the impact of bias correction may differ depending not just on the direction of learning, but also on the individual's prior belief about where she was in the distribution, such as if the prior was that she was rich or poor. This hypothesis is a more realistic amendment of the previous one, as correcting beliefs about one's prior may not always have equivalent directional effects. The effect of bias correction on preferences should be greater when it reinforces the priors of individuals about their relative position in the income distribution. Again, it is helpful to think of the comparison between two individuals who are equivalently biased; assume they share the same belief that they are poor. The logic is that the information revelation to the treated individual reveals that she is poorer than she thought, and thus she would be more progressive in preferences relative to the individual who believes she is poor, but does not in fact learn that she poorer than she thought. We can expect a symmetrical effect for individuals who believe they are rich and learn they are richer than they thought, relative to individuals who believe they are rich but do not receive the same bias-correcting information. Thus we specify predictions for the two ends of the prior and bias-correction spectrum, for people whose priors were that they were poor and learn they are poorer, and for people who believe they are rich and learn they are richer. This leads to the following hypotheses that condition information effects based on specific priors:

H3a: Individuals who believe they are poor but learn they are relatively poorer than they thought should be more supportive of progressive taxation relative to individuals who are equally misinformed, but who do not learn their true position in the income distribution. 
H3b: Individuals who believe they are rich and learn they are relatively richer than they thought should be less supportive of progressive taxation relative to individuals who are equally misinformed, but who do not learn their true position in the income distribution. ${ }^{29}$ Our third set of hypotheses argues that the magnitude of bias correction should matter for tax progressivity preferences. Simple directional bias alone (merely learning that one is richer or poorer than one thought) may not be relevant if the degree of bias is little. For example, if one learns that he is relatively richer than his prior, but if both his prior and actual position are relatively rich (such $80^{\text {th }}$ and $90^{\text {th }}$ percentiles, respectively), there may be a limited impact of such information (he may be less progressive, but the magnitude may be small). A similar contrast is if the citizen learns he is relatively poorer, but the magnitude of learning is small. Intuitively, learning that one is one decile richer or poorer than thought should have a smaller effect on preferences than learning that one is three deciles away from one's prior. Hence we expect the treatment effect to differ depending on how many deciles one is corrected by, irrespective of the prior. This leads to $\mathrm{H} 4$.

H4: Individuals whose bias-correcting information on income is greater (in terms of the distance between their subjective relative income and their actual income) should have larger differences in tax progressivity preferences (in the direction expected by H2) relative to similarly mistaken individuals in the control group.

Our final set of hypotheses refer to the relevance of the actual income learned (one's revealed actual placement in the income distribution). We expect that bias correction—learning that one is relatively richer or poorer-should matter conditional on the individual learning that he is in a particular income group, as opposed to simply the magnitude of bias correction.

\footnotetext{
${ }^{29}$ We do not have clear ex ante predictions for individuals who believe they are poor but learn they are richer, nor for individuals who believe they are rich but learn they are poorer.
} 
Revelation that one is in a particular income group could matter regardless of one's measured prior or magnitude. Individuals who learn they are in a poor income category, for instance, regardless of their prior and positive or negative bias, should be more progressive than individuals who have the same bias but do not learn. Similarly, those who learn they are in a rich income category (regardless of prior), should be less progressive than those who are also mistaken but do not learn. ${ }^{30}$ Thus we finally have

H5a. Individuals who learn that they belong to low-income groups should be more supportive of progressive taxation relative to individuals who belong to those groups and are not informed.

H5b. Individuals who learn that they belong to high-income groups should be less supportive of progressive taxation relative to individuals who belong to those groups and are not informed.

We now describe the research design that enables us to test these hypotheses.

\section{Section 3: Design and measurement}

Sample. To test the above hypotheses, we gathered data using a web-based survey of 4,000 respondents in Spain in July 2012. The survey was administered by Netquest, a Spanish survey firm. The resulting sample has similar demographic composition to large nationally representative surveys in Spain (i.e. those fielded by the main public survey center, the Center for Social Investigation (CIS)), with the exception of a deliberate oversample of Catalonia (the subsample for Catalonia is 1,200). ${ }^{31}$ Respondents were randomly assigned to a control group

\footnotetext{
${ }^{30}$ Note this is a distinct hypothesis from H3, because $\mathrm{H} 5$ does not have any predictions based on priors. This hypothesis is also relevant for those who have the correct prior, as those individuals may also be unsure of their prior, and thus the information confirms their belief that they are in a particular income group.

${ }^{31}$ The supplemental online appendix (SOA) gives an overview of Netquest's stratification and sampling strategy and compares our survey to others using standard representative sampling procedures on the relevant social and demographic variables. It shows almost no statistically significant differences in the distributions of these variables between the surveys. Our sample has however a slight oversample of younger respondents. The oversample of
} 
(with probability .25), a priming treatment group (with probability .25), and an information treatment group (with probability .5). We describe the rationale for the treatment groups below. Measuring tax rate and tax progressivity preferences. We focused on a set of variables capturing preferences over taxation of incomes. Respondents were first asked what percentage of a household income should be paid in taxes if the household monthly income is 1,200 euros. ${ }^{32}$ They were then asked the same preferred tax rate question for incomes for a family earning 2,100, 3,200, and 10,000 euros per month, respectively, and were permitted to modify these responses before completing this module. ${ }^{33}$ We focus on measuring preferences over effective tax rates as opposed to marginal tax rates for a several reasons. First, the preferences over effective tax rates are key aspects of theoretical models of redistribution. Second, preferences over such rates give a more accurate sense of respondents' "post taxation fairness" that we seek to explain. Third, the concept of effective tax rates is more straightforward for citizens to understand, and variation in this view should be less sensitive to changes in the income categories asked, as opposed to questions about marginal tax rates.

We use these respondents' tax preferences to calculate different measures of preferences of tax progressivity. The data on tax preferences of four income categories allows us to focus on two simple measures of progressivity. ${ }^{34}$ The first measure is the ratio of the top tax rate to the

Catalonia is due to a separate module of questions that deal with Catalonia-specific issues. All estimations discussed in the results section include weights for Catalonia but the unweighted results are substantively similar.

${ }^{32}$ In Spain monthly pre-tax incomes are most well-known and salient. The Spanish wording of the question is: “Como usted sabe, para poder ofrecer servicios a los ciudadanos, el Estado necesita recaudar impuestos. ¿Qué porcentaje de sus ingresos cree usted que debería pagar en impuestos un hogar español medio, cuyos ingresos mensuales totales, antes de pagar impuestos, sean de [insert euro amount] euros al mes?” Part D of the SOA provides screenshots of the relevant questions.

${ }^{33}$ The incomes chosen represent roughly different decile cut-offs. For a three-person household (the modal household in Spain), 1,200 euros a month is roughly at the $20^{\text {th }}$ percentile; 2,100 euros a month is roughly at the $50^{\text {th }}$ percentile; 3,400 euros is at the $80^{\text {th }}$ percentile; 10,000 euros is roughly in the $95^{\text {th }}$ percentile. We drop 44 cases of inconsistent non-monotonic responses; substantive results are not affected by inclusion of these cases (these very likely represent cases of survey satisficing).

${ }^{34}$ See Kakwani (1977); (Stroup, 2005). For a review see Urban (2009). 
bottom tax rate (incomes of 10,000 euros versus 1,200 euros). ${ }^{35}$ As the distribution of this variable is highly skewed because of a limited number of outliers, in the analyses that follow, we $\log$ this ratio. The second measure of progressivity preferences is the standard income concentration ratio known as the Kakwani coefficient. ${ }^{36}$ This concentration coefficient (C) can be easily calculated via the following expression:

$$
C=2 \frac{\sum_{t=1}^{T} f_{t} \cdot \mu_{t} \cdot R_{t}}{\mu}-1 \text { (Eq. 1) }
$$

where $f_{t}$ refers to the population share of group $t, \mu_{t}$ its tax rate, $R_{t}$ is the fractional rank in the income distribution, and $\mu$ the overall tax rate ${ }^{37}$ This coefficient is zero if all groups are taxed equally and 1 if only the highest-income group is taxed. A higher concentration coefficient indicates greater progressivity of the proposed tax scheme. ${ }^{38}$

Measuring perceived income. Perceived income or subjective relative income was measured by asking respondents approximately what percentage of households in Spain earns less than them, and what percentage of households earns more. To reduce measurement error, both numbers had to sum to 100 , and respondents were prohibited from providing percentages ending in 0 , to prevent them from choosing the satisficing " 50 percent” response, and to facilitate the classification of respondents in income deciles. These percentages were then transformed into an income decile for each respondent, adjusting for household size.

\footnotetext{
${ }^{35}$ To avoid listwise deletion of data regarding calculation of ratios and logged ratios, we impute all "0's" with "1." The estimation results using neither preferred log ratios nor Kakwani coefficients do not substantively change. ${ }^{36}$ Kakwani (1977). For use of this index in other policy contexts, see Prasad and Deng (2009).

${ }^{37}$ To compute the concentration coefficient we assume that all four income groups that the respondent is asked about are of equal size. The initial component in the numerator of equation 1 is then $(.25 *$ tax rate on $1200 * .125)+$ $(.25 *$ tax rate on $2100 * .375)+(.25 *$ tax rate on $3400 * .625)+(.25 *$ tax rate on $10000 * .875)$. Future variants of this question might vary the proportions of the population with these incomes, and specify such proportions to the respondent.

${ }^{38}$ Costa-Font and Gil calculate a Kakwani index for the actual Spanish tax system of 0.38 (2008).
} 
Treatments. The respondents were randomly assigned to one of three experimental groups, with each group receiving a slightly different version of the survey. In group one, the control group, respondents were first asked the tax rates questions, and then asked the relative income question.

We also randomly assigned individuals to an experimental group which simply reverses the order of the income self-placement and taxation questions. In this second group, respondents were first asked the subjective income placement question about what percentage of households in Spain earn less and what percentage earn more. We use this design to anticipate concerns about order effects and priming, as exemplified in the vast literatures on both topics that indicates the longstanding importance of how making some policy issues salient can affect attitudes on others. ${ }^{39}$ We are circumspect that asking citizens to consider their relative income position may affect subsequent views of preferred taxation, and vice versa. This design feature allows us to assess our bias correction and information treatment, discussed below, netting out all priming effects, a design aspect absent in previous studies. ${ }^{40} 25$ percent of respondents were assigned to each of these two groups.

In group three, the "information” or "bias correction” treatment group, respondents were also asked the subjective income placement question about the percentage of households in Spain earning less and more than they do. But after providing a response, they read a web screen that informed them of the true percentage of households that earn less and the percentage of

\footnotetext{
${ }^{39}$ Iyengar and Kinder (1987); Miller and Krosnick (2000); Lenz (2009). As an example of priming studies in a European context, see Van der Brug, Semetko, and Valkenburg (2007).

${ }^{40}$ Priming individuals to think about their position in the distribution of income across households by asking them where they think they are in the income distribution could affect the preferred level of progressivity. The information design was conceived independently of the Cruces et al. (2013) study, and we build upon that study by providing relative income information in an advanced industrialized state, examining tax preferences specifically, accounting for potential priming effects, and testing additional hypotheses of the impact of information on tax preferences.
} 
households that earn more; these percentages were based on the respondent's actual income decile (see below for derivation of the respondent's objective decile). The individuals then answered the same series of questions about preferred tax rates on different incomes as in the other two groups. This experimental assignment allows us to assess the impact of information on one's objective or true position in the income distribution on tax progressivity preferences. Group three hence only differs from group two in that respondents were informed of their correct place in the income distribution. Half the respondents were assigned to this group. Table 1 displays the treatment assignment. ${ }^{41}$

Table 1: Experimental Design

\begin{tabular}{|c|c|c|c|}
\hline $\begin{array}{c}\text { Experimental } \\
\text { Group }\end{array}$ & $\begin{array}{c}\text { Information } \\
\text { Treatment }\end{array}$ & $\begin{array}{c}\text { Relative Income } \\
\text { Asked First }\end{array}$ & Probability of \\
Assignment
\end{tabular}

Measuring Income. Several challenges to this design require precise measurement of the respondent's income and income decile. First, we had to measure income prior to the information treatment so that for those in group 3, respondents could be informed of their actual income deciles. Second, the design had to minimize measurement error of income and elicit truthful responses. Third, our instrument of measuring respondent income had to be conducted in a way so as not to inform or signal to the respondent of his actual relative income position. We avoid directly asking respondents their income in an open-ended response, as this could result in higher

\footnotetext{
${ }^{41}$ Successful randomization of respondents into each experimental group is shown in the online appendix C.
} 
measurement error, as well as a higher probability of non-response and non-completion of the questionnaire. Further, such responses may not be truthful, and bias could exist in the type of respondent willing to give such information. The standard approach taken by surveys such as the European Social Survey and many national-level surveys is to ask respondents to self-place themselves in pre-defined income categories. This survey instrument has the advantage of avoiding forcing the respondent to provide an actual raw income number, and this less invasive question generally helps retain response rates. However, providing to the respondent truthful deciles or other incremental income categories greatly risks informing the respondent about her true position in the income distribution. ${ }^{42}$ The respondent's subsequent reported relative income placement could be influenced by the survey instrument of ascertaining his actual income.

To address this problem we ascertain the respondent's income decile, correcting for household size, in the following way. Early in the survey the respondent provides data on his household size. On the basis of the composition of the household, we calculate the income thresholds that separate income deciles according to the 2010 national income distribution in Spain. The data used to classify income deciles is from the Encuesta de Condiciones de Vida (2010), the national representative survey conducted by the Spanish Statistical Institute (INE) which is part of the international Luxembourg Income Study. To compare incomes from households of different size, we use the standard OECD equivalence scale, which weights the total household income by the square root of the number of members of the household. For example, for a two-member household, the income deciles are defined by the following cut-off points (numbers were rounded to the nearest multiple of 50): €700, €1000, €1200, €1450, €1700,

\footnotetext{
${ }^{42}$ Gallego demonstrates with survey experimental evidence that the way in which income categories are presented affects levels of social trust, possibly by affecting the perceived level of inequality (2013).
} 
$€ 2000$, €2300, €2750 and €3600. For each household size, there were nine different cut-off points that could be randomly shown to the respondent.

One of these nine decile cut-off points is randomly presented to the respondent. The respondent is then asked whether her household income is above or below that number. If the response is above (below) the randomly chosen number, then one of the higher (lower) cut-off points is selected randomly, and the same question (if the respondent's household income is above or below the threshold) is asked again. This process is iterated until the respondent can be unambiguously assigned to one income decile. In the survey nearly 44 percent of respondents could be classified by responding to only three "higher/lower" questions and 73 percent respondents were placed in the correct decile within four questions. This approach of income measurement has several advantages. It is a more precise measurement of respondent income because of the normalization by household size; it allows for accurate measurement of respondent income without giving any information to the respondent about the national distribution of income; and finally, the method allows for high rates of response as opposed to more open-ended income questions. ${ }^{43}$

Independent variables. In addition to accurately coding respondent income according the process described above, we also gathered data on respondent gender, age, political ideology, education, and labor market status. Female is coded as 1. Education is coded on a three-point scale, with each category referring to attainment of compulsory education, non-compulsory secondary education, and tertiary education. Age is coded linearly. Political ideology is the standard 10 point scale, with 1 being most left-wing and 10 being most right-wing.

\footnotetext{
${ }^{43}$ We test for anchoring effects by controlling for the first threshold number that a respondent was randomly asked. We find no evidence that the initial threshold asked affects preferences on any of the dependent variables. We also find no effect of the number of threshold points that the respondent had to answer on outcomes.
} 


\section{Section 4: Results}

In this section we test the above hypotheses by presenting two sets of results: first, we discuss the observational results within the control group to test hypotheses on the correlates of perceived decile and progressive taxation. Second, regarding the latter four hypotheses, we test the treatment effects of information on true income position on tax preferences. Critically, to make correct inferences about just the role of information, we compare the treatment results of group 3 to those of group 2, as in those two groups the order of the questions is the same. The design intent is to isolate the causal impact of information on one's relative income position to those not receiving information. Interested readers can consult the online appendix for specific results that compare group 2 to group 1 (where the relative income question and taxation question orders are reversed, and no information treatment is given). Table A of the appendix presents the descriptive statistics of the sample.

Observational results from the control group

Before turning to test hypotheses, we first present basic descriptive data on the degree to which individuals underestimate or overestimate their relative income. Nearly 15 percent of respondents accurately place themselves in the correct income decile, 40 percent of individuals are poorer than they believe, and 45 percent of respondents are richer than they believe. If we expand the definition of "accurate" self-placement to be within one decile above or below the correct decile, approximately only 40 percent of respondents are accurate. Figure 1 displays the overall distribution of perceived deciles and our calculation of each respondent's actual income deciles according to the methodology described above. The distribution of actual income deciles is rather uniform, suggesting that the survey sample is representative of the Spanish population in terms of income. The figure also reveals that there is not a clear overlap between perceived 
income position and real income position; respondents in neither poorer nor richer deciles accurately place themselves in those categories. Respondents tend to perceive themselves as more middle-income than they really are. ${ }^{44}$ This phenomenon occurs at both ends of the income distribution — poorer individuals are likely to perceive themselves to be richer than they are, and richer individuals are likely to perceive themselves as poorer than they actually are. ${ }^{45}$ The average difference among individuals who mistakenly believed they were richer is 2.7 deciles; the average difference among individuals who mistaken believed they were poorer is 2.3 deciles.

Figure 2 displays this misperception in the control group in a different way by displaying for each actual decile the mean self-placement within each group. As individuals become richer, their mean-self placement also increases. However, the bottom 40 percent of the income distribution perceives itself as being mostly in the $40^{\text {th }}$ to $50^{\text {th }}$ percentile range. The top three deciles place themselves on average as below the $70^{\text {th }}$ percentile. These initial descriptive statistics indicate much misperception of relative income, and that such misperception is not limited to a particular income group.

We now test hypothesis 1a, and find confirmation in documenting a sensible correlation between objective or actual income and perceived income category; however, we note that objective income (as discussed above) does not nearly fully explain actual perceived income. We estimate a simple OLS model where the dependent variable is perceived income decile. Table 2 displays the results. We control for a standard set of demographic variables, including the actual decile (measured with the method of the previous section), female gender, age, education, labor

\footnotetext{
${ }^{44}$ We tested for differences in perceived decile across the three treatment groups and found no statistically significant differences.

${ }^{45}$ Table B of the appendix presents results of OLS regressions in which the dependent variable is the absolute difference between the perceived income decile and the actual income decile (i.e. how "wrong" each respondent is). While we find that actual income, age, and educational attainment tend to be associated with smaller errors, all sociodemographic characteristics combined explain less than four percent of the variation in self-placement error.
} 
market status, and political ideology. Because the dependent variable is perceived decile, positive values indicate that the individual is more likely to believe that she is relatively rich. We find as expected that actual decile explains some of the variation (as Figures 1-2 show), but note that the overall r-squared is only $0.11 .{ }^{46}$ Individuals who are female, unemployed, and have lower education levels tend to perceive themselves as poorer, even after controlling for their actual income. Column 3 in Table 2 presents results of a model that controls for two binary variables to test for the possibility that the different ordering of the questionnaire might affect the self-perceived position in the income distribution. However, this does not seem to be the case. ${ }^{47}$

\footnotetext{
${ }^{46}$ Cruces et al. (2013) also control for respondent perceptions of within locality rank, which we do not have data on. ${ }^{47}$ We find similar results regarding perceived versus actual income decile using a different dataset. We inserted the same perceived decile question in a separate representative Spanish household survey fielded in July 2012 (n=1000); the response rate for the household income question was 78 percent. We find that approximately 14 percent of respondents accurately place themselves in the correct decile; that poorer respondents over-rank themselves and richer respondents under-rank themselves; and that the average errors among respondents for those who are incorrect are 2.4 and 2.3, respectively. Results for the perceived relative income question for this separate omnibus survey are available upon request.
} 
Figure 1. Distribution of Self-Perceived Income Decile and Actual Income Decile

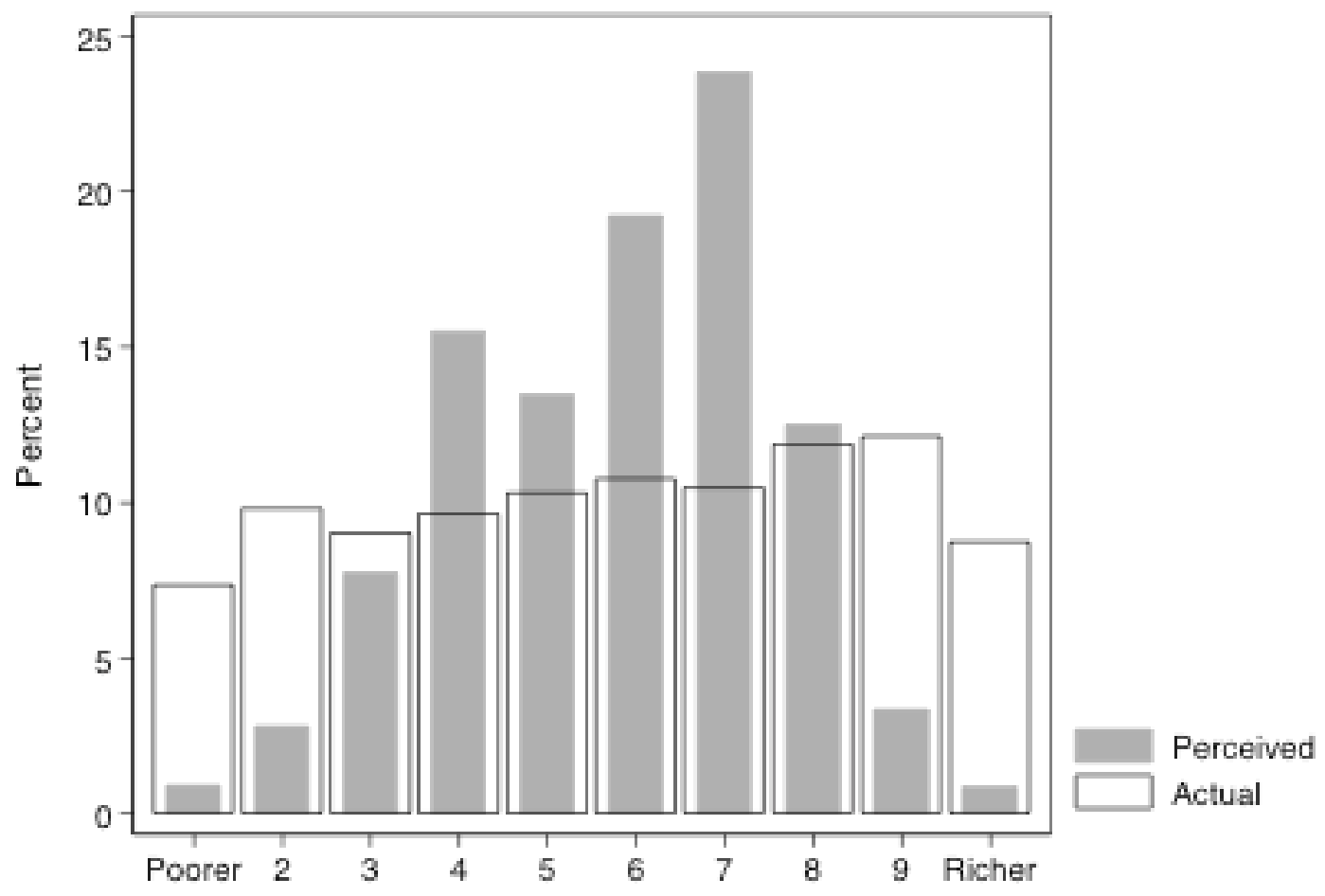

Figure 2. Average Perceived Decile by Income Group

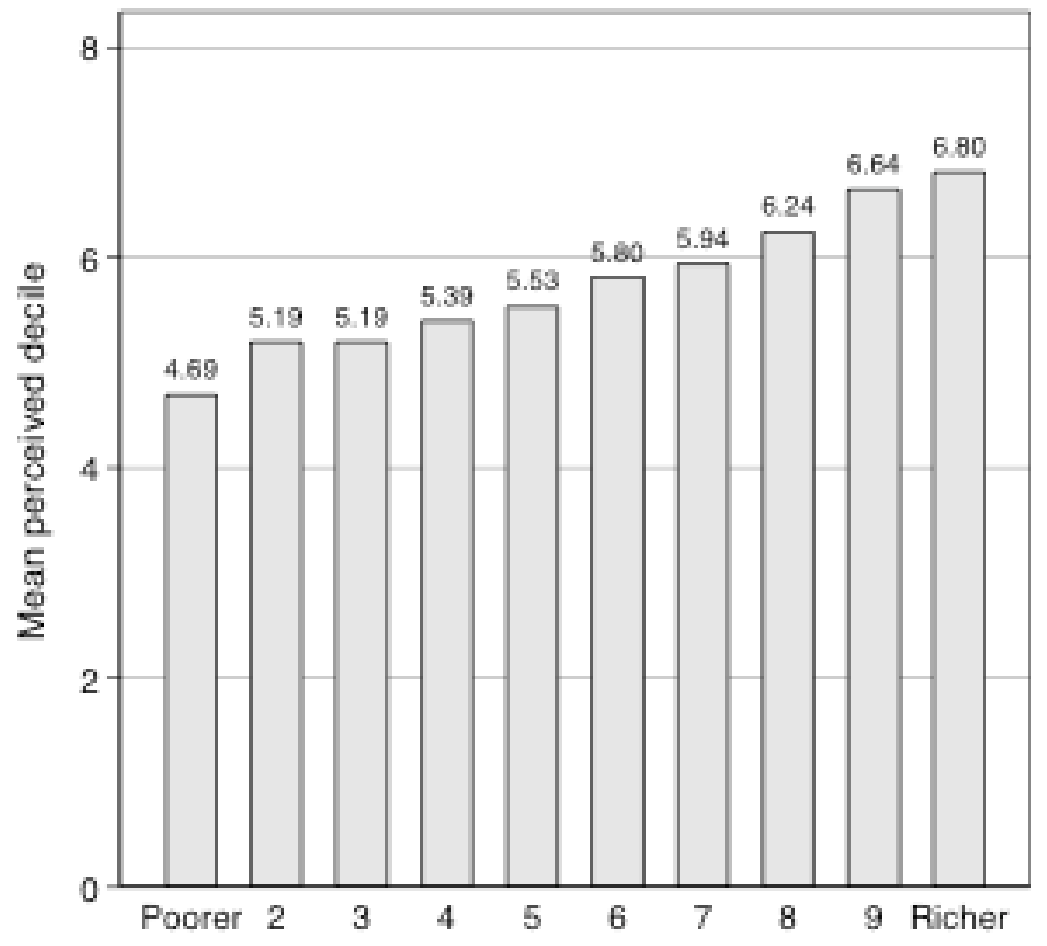




\section{Table 2: Explaining Perceived Income Decile}

(1)

$0.21^{* * *}$
$(0.010)$

Ideology

Age

Female

Unemployed

Household size

Education

Priming treatment

Info treatment

Constant

$N$

$R^{2}$

Standard errors in parentheses

${ }^{*} p<0.10,{ }^{* *} p<0.05,{ }^{* * *} p<0.01$
(2)

$0.19^{* * *}$

(0.012)

$0.19^{* * *}$

(0.012)

$-0.0026$

$-0.0024$

(0.013)

(0.013)

$-0.0018$

$-0.0019$

(0.0026)

(0.0026)

$-0.13^{* *}$

$-0.13^{* *}$

(0.060)

$(0.060)$

$-0.18^{* *}$

$-0.18^{* *}$

(0.077)

$(0.077)$

$0.10^{* * *}$

$0.10^{* * *}$

(0.025)

(0.025)

$0.20^{* * *}$

(0.047)

$(0.047)$

0.12

(0.082)

0.025

(0.072)

$4.09^{* * *}$

$4.05^{* * *}$

(0.20)

(0.21)

3378

3378

0.120

We now turn to explaining preferences for tax progressivity in the control group, using the two measures of progressivity described above to test hypothesis 1b. Most respondents (82 percent) favor some degree of tax progressivity. The average preferred ratio of those making 10,000 euros a month to 1,200 euros a month is 8.6 , with a standard deviation of nearly 12 (due to some with extreme preferences of taxation of the wealthy at nearly 100 percent). Individuals who perceive themselves to be relatively poorer (those below the $50^{\text {th }}$ percentile) prefer a higher ratio than those above the $50^{\text {th }}$ percentile $(8.1 \mathrm{v} 7.5, p<.08)$. The median preferred effective tax rate on those making 10,000 euros per month is 28 percent, whereas the median preferred rate for 
those making 1,200 euros per month is 6.7 percent. The mean for preferred Kakwani tax concentration coefficient (C) is approximately .30 (with standard deviation of .16).

What explains the variation in tax progressivity preferences? Table 3 display results of OLS estimation models with the two progressivity measures as dependent variables. We find that for both measures of progressivity, consistent with a class of standard political economy models, perceived decile is negatively correlated with progressivity preferences. The richer the respondent perceives herself to be, the less progressive their preferred tax scheme. Further, as Table 3 shows, when we control for individuals’ perceived income, the variable theorized to be driving tax preferences in many political economy models, this variable has a similar magnitude than the individual's actual income. Actual income is actually statistically insignificant in explaining the variation in concentration coefficient, once other demographic controls are considered. These observational results from the control group indicate the potential empirical and theoretical value in assessing the degree to which bias correction treatments in terms of simple information about actual relative income perception affect such tax preferences, given the importance of the perceived decile variable in the control group. In terms of other covariates, political ideology operates in an expected direction, as more conservative individuals prefer lower progressivity ratios and concentrations. Older and female individuals tend to favor more progressivity. 
Table 3: Explaining Preferences for Tax Progressivity in the Control Group

Log Ratio

Decile

Perceived decile

Ideology

Age

Female

Unemployed

Household size

Education

Constant

$\mathrm{N}$

$\mathrm{R} 2$

Standard errors in parentheses

${ }^{*} p<0.10,{ }^{* *} p<0.05,{ }^{* * *} p<0.01$
(1)

(2)

Concentration

$-0.0025$

(0.0020)

$-0.0083^{* * *}$

(0.0027)

$-0.0075 * * *$

(0.0022)

$0.0018^{* * * *}$

(0.00041)

(0.0027)

$0.030 * * *$

(0.0097)

(0.065)

0.0057

(0.013)

(0.086)

$0.0083^{* *}$

(0.0041)

$(0.027)$

$-0.0089$

(0.0072)

(0.048)

$0.30 * * *$

$1.56 * * *$

(0.033)

(0.22)

814

814

0.073 


\section{Experimental results: The impact of information}

We now test hypotheses 2-5 about the impact of informing individuals of their actual place in the income distribution. Unless otherwise specified, the format of the analysis for testing all hypotheses is as follows: the baseline estimations are OLS models where the dependent variables are both the log ratios and the progressivity concentration coefficients. In these estimations, we control for treatment assignment, a binary variable indicating the direction of bias of the respondent (if she believes she is poorer or richer than she actually is), and where appropriate, the interaction of these variables. The binary variable "poorer than thought" classifies individuals who perceive themselves as richer than they actually are, thus they are in fact "poorer" than they believe; this variable is called poorer. This allows one to interpret the interaction term between this variable and treatment assignment as the effect of learning that one is poorer, relative to those in group two who are also poorer than they believe, but do not learn so. The interaction term is labeled learn poorer. We also include a variable "correct" that indicates that the respondent correctly places herself in the income decile she actually belongs to, and hence the interaction term between this correct belief and information treatment can be interpreted as the impact of learning that one is correct, relative to those who are correct but do not learn so. This variable is labeled learn correct. In all tables, we display results of estimations that control for these treatment indicators as well as demographic variables.

We first test hypotheses 2a-2b, which specify a simple directional impact of information ${ }^{48}$; individuals who learn they relatively poorer than they thought should be more supportive of progressive taxation relative to individuals who are equally misinformed, but who do not learn their true position in the income distribution. Further, we hypothesize the opposite

\footnotetext{
${ }^{48}$ This is the main claim tested in Cruces et al. (2013).
} 
effect for individuals who learn they are richer than they thought. Table 4 present simple tests of hypotheses $2 \mathrm{a}-2 \mathrm{~b}$ with respect to the outcome of preferred ratios of tax rates, testing for baseline directional effects. Columns 1-3 consider the outcome of tax rate ratio preferences, while columns 4-6 consider the outcome of the concentration coefficient. The coefficient of interest across all models is the variable info treatment, which is the binary indicator for treatment assignment. Each column examines the separate impact of learning one's true decile conditional on the prior of thinking that the respondent is poorer than he is (thus he learns he is poorer), richer than he is (he learns he is richer), and is correct (he learns he is correct), relative to the baseline category of respondents who are equivalently mistaken but do not learn. All models control for relevant demographic variables. Across all specifications, we observe that the coefficient for treatment assignment is not precisely estimated by conventional standards, indicating no average directional effect. ${ }^{49}$ Overall, then, we find little confirmation of hypothesis 2a-2b, which predict just straightforward "learn richer" or "learn poorer" directional effects. This null effect should be not too surprising, as the impact of information on tax preferences should matter conditional on other factors, such as one's priors, the magnitude of information, and the final position learned, which we now turn to.

\footnotetext{
${ }^{49}$ We also obtain substantively small and imprecisely estimated main treatment coefficients when we do not control for relevant demographic characteristics, but do not show them due to space constraints.
} 
Table 4: Baseline directional learning effects

\begin{tabular}{|c|c|c|c|c|c|c|}
\hline & $\begin{array}{c}(1) \\
\log \text { ratio } \\
\text { Prior is poorer }\end{array}$ & $\begin{array}{c}\text { (2) } \\
\log \text { ratio } \\
\text { Prior is richer }\end{array}$ & $\begin{array}{c}\text { (3) } \\
\log \text { ratio } \\
\text { Prior is correct }\end{array}$ & $\begin{array}{c}\text { (4) } \\
\text { concentration } \\
\text { Prior is poorer }\end{array}$ & $\begin{array}{l}\text { (5) } \\
\text { concentration } \\
\text { Prior is richer }\end{array}$ & $\begin{array}{c}\text { (6) } \\
\text { concentration } \\
\text { Prior is correct }\end{array}$ \\
\hline Info treatment & $\begin{array}{c}0.052 \\
(0.055)\end{array}$ & $\begin{array}{l}-0.032 \\
(0.052)\end{array}$ & $\begin{array}{c}0.074 \\
(0.096)\end{array}$ & $\begin{array}{c}0.0016 \\
(0.0080)\end{array}$ & $\begin{array}{l}0.00031 \\
(0.0082)\end{array}$ & $\begin{array}{l}0.0086 \\
(0.014)\end{array}$ \\
\hline Decile & $\begin{array}{c}-0.040 * * \\
(0.016)\end{array}$ & $\begin{array}{c}-0.046 * * * \\
(0.016)\end{array}$ & $\begin{array}{l}-0.012 \\
(0.025)\end{array}$ & $\begin{array}{l}-0.0033 \\
(0.0023)\end{array}$ & $\begin{array}{c}-0.0093 * * * \\
(0.0024)\end{array}$ & $\begin{array}{l}-0.0035 \\
(0.0036)\end{array}$ \\
\hline Age & $\begin{array}{c}0.0094 * * * \\
(0.0023)\end{array}$ & $\begin{array}{l}0.012 * * * \\
(0.0022)\end{array}$ & $\begin{array}{c}0.0034 \\
(0.0040)\end{array}$ & $\begin{array}{c}0.0012 * * * \\
(0.00033)\end{array}$ & $\begin{array}{c}0.0018 * * * \\
(0.00035)\end{array}$ & $\begin{array}{c}0.00062 \\
(0.00058)\end{array}$ \\
\hline Female & $\begin{array}{c}0.087 \\
(0.054)\end{array}$ & $\begin{array}{l}0.12 * * \\
(0.052)\end{array}$ & $\begin{array}{c}0.096 \\
(0.095)\end{array}$ & $\begin{array}{c}0.015 * \\
(0.0078)\end{array}$ & $\begin{array}{c}0.024 * * * \\
(0.0080)\end{array}$ & $\begin{array}{c}0.017 \\
(0.014)\end{array}$ \\
\hline Education & $\begin{array}{c}-0.11 * * * \\
(0.040)\end{array}$ & $\begin{array}{l}-0.036 \\
(0.044)\end{array}$ & $\begin{array}{l}-0.082 \\
(0.073)\end{array}$ & $\begin{array}{c}-0.015^{* * *} \\
(0.0058)\end{array}$ & $\begin{array}{l}-0.0045 \\
(0.0069)\end{array}$ & $\begin{array}{l}-0.011 \\
(0.011)\end{array}$ \\
\hline Unemployed & $\begin{array}{c}0.017 \\
(0.059)\end{array}$ & $\begin{array}{l}-0.0085 \\
(0.083)\end{array}$ & $\begin{array}{l}-0.088 \\
(0.12)\end{array}$ & $\begin{array}{l}0.00038 \\
(0.0085)\end{array}$ & $\begin{array}{l}-0.0022 \\
(0.013)\end{array}$ & $\begin{array}{l}-0.016 \\
(0.018)\end{array}$ \\
\hline Constant & $\begin{array}{c}1.57 * * * \\
(0.15)\end{array}$ & $\begin{array}{c}1.43^{* * *} \\
(0.19)\end{array}$ & $\begin{array}{c}1.58 * * * \\
(0.27)\end{array}$ & $\begin{array}{c}0.28 * * * \\
(0.022)\end{array}$ & $\begin{array}{c}0.28 * * * \\
(0.030)\end{array}$ & $\begin{array}{c}0.29 * * * \\
(0.040)\end{array}$ \\
\hline $\begin{array}{l}N \\
R^{2}\end{array}$ & $\begin{array}{l}1079 \\
0.038\end{array}$ & $\begin{array}{l}1087 \\
0.040\end{array}$ & $\begin{array}{c}350 \\
0.012\end{array}$ & $\begin{array}{l}1079 \\
0.028\end{array}$ & $\begin{array}{l}1087 \\
0.046\end{array}$ & $\begin{array}{c}350 \\
0.016\end{array}$ \\
\hline
\end{tabular}

Standard errors in parentheses

* $p<0.10,{ }^{* *} p<0.05,{ }^{* * *} p<0.01$ 
Hypotheses 3a-3b predict that individual priors regarding their position in the income distribution should condition any directional learning effect. Individuals who believe they are poor but learn they are relatively poorer than they thought should be more supportive of progressive taxation relative to individuals who are equally misinformed, but who do not learn their true position in the income distribution; we expect symmetrical opposing effects for those who believe they are rich but learn they are richer. Figures 3a and 3b first display the basic treatment effects on the log of the preferred tax ratios, dividing among those individuals whose prior was they were poor and those who had a prior they were rich. The figure indicates that among the self-perceived poor, learning that one is poorer does make taxation preferences more progressive, but has no such effect for those with the prior that they were rich.

\section{Figures 3a-3b. Information effects and priors}
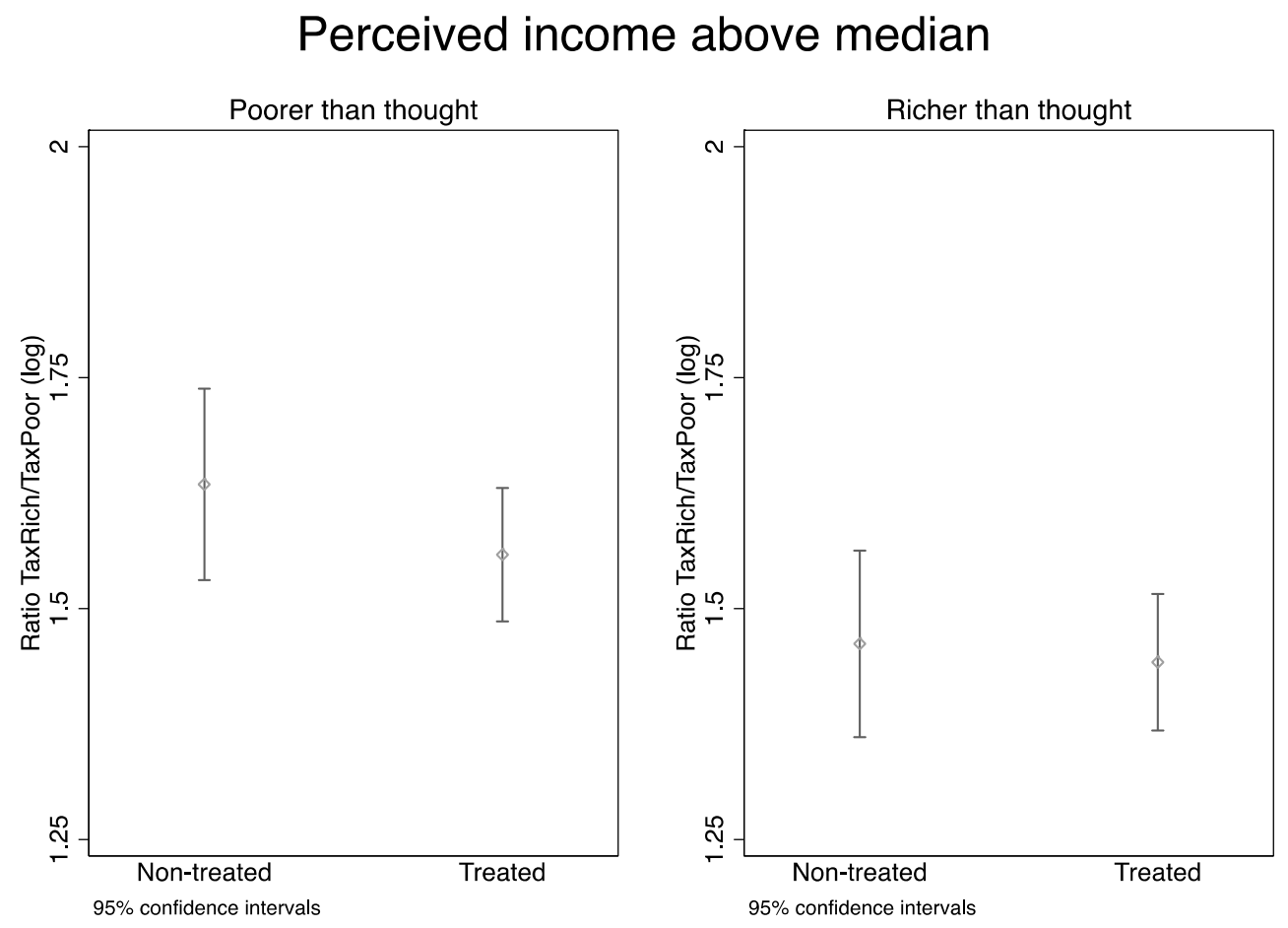


\section{Perceived income below median}
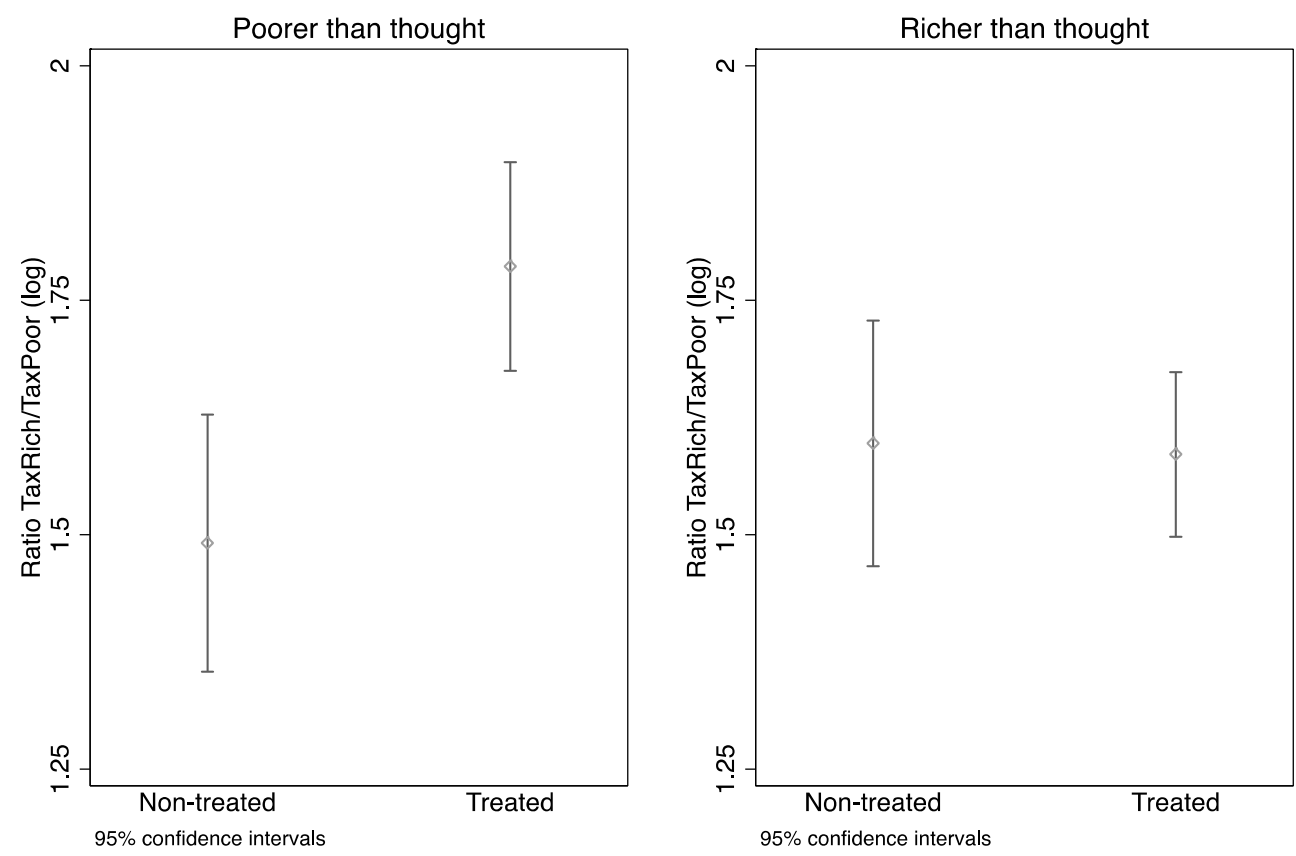

Tables 5-6 present the estimation results. Table 5 presents the information treatment effects for those who learn they are poorer conditioning on those whose prior was that they were poor. Table 6 does so for those who learn they are richer, conditioning on those who prior was that they were rich. The first two columns in both tables examine ratios of tax rates; the latter two columns of both tables examine the progressivity concentration coefficient. Recall that all effects are interpreted relative to the group that was asked to place themselves on the income distribution, and were then asked tax questions without being informed of their position; this constitutes the proper comparison group. In Table 5, the coefficient of interest is the interaction term between the information treatment and learning that one is poorer. This term is called Learn poorer. We note that across all specifications (regardless of which taxation outcome and whether we control for demographic characteristics), this information effect conditioning is precisely estimated. In Table 6, analogously the coefficient of interest is the interaction term 
between the information treatment, and learning that one is richer. This term is called Learn richer. By contrast in this table, across all specifications the interaction term is substantively small and imprecisely estimated.

The balance of evidence from these two tables indicates much stronger evidence of hypothesis 3a—individuals who believe they are poor but learn they are poorer are more progressive than those not informed - than hypothesis 3b—those who believe themselves to be rich do not seem to be responsive to the information treatment. In terms of substantive effects, regarding support for higher tax ratios, the effect of the information is precisely estimated and the size of the effect is about one third of a standard deviation of the log ratio variable. Note as well that the "poorer than thought" variable is negatively correlated with tax progressivity as measured by high versus low tax ratios. This means that these individuals who are poorer than they actually believe (they mistakenly believe themselves to be richer) have less progressive tax preferences compared with those who are actually richer than they believe (the baseline category), but this impact is offset by learning that one is poorer. We note that among the selfperceived poor who learn that they are richer than they thought, no effect on tax progressivity preferences exists. Likewise, for individuals who believe that their household income is above the median, learning that one is richer or poorer does not affect preferences for tax progressivity either. One speculative reason why we observe these asymmetrical effects is that if there is some degree of altruism or inequality aversion among richer individuals, the null effect among those who learn they are richer is due to standard self-interest and altruist models operating in opposite directions. If a subset of individuals who learn they are richer are inequality averse, they may then prefer high taxation rates, contra traditional self-interested models. We return to this possibility in the conclusion. 
Table 5: Information Effects Conditioning on Priors of Being Poor

\begin{tabular}{|c|c|c|c|c|}
\hline & $\begin{array}{c}(1) \\
\text { Log ratio }\end{array}$ & $\begin{array}{c}(2) \\
\text { Log ratio }\end{array}$ & $\begin{array}{c}\text { (3) } \\
\text { Concentration }\end{array}$ & $\begin{array}{c}\text { (4) } \\
\text { Concentration }\end{array}$ \\
\hline Info treatment & $\begin{array}{c}0.014 \\
(0.074)\end{array}$ & $\begin{array}{l}0.0092 \\
(0.073)\end{array}$ & $\begin{array}{l}0.0052 \\
(0.011)\end{array}$ & $\begin{array}{l}0.0042 \\
(0.011)\end{array}$ \\
\hline Poorer & $\begin{array}{l}-0.060 \\
(0.099)\end{array}$ & $\begin{array}{l}-0.21 * \\
(0.12)\end{array}$ & $\begin{array}{c}-0.017 \\
(0.015)\end{array}$ & $\begin{array}{c}-0.039 * * \\
(0.017)\end{array}$ \\
\hline Learn poorer & $\begin{array}{l}0.29 * * \\
(0.12)\end{array}$ & $\begin{array}{c}0.31 * * * \\
(0.12)\end{array}$ & $\begin{array}{l}0.032^{*} \\
(0.018)\end{array}$ & $\begin{array}{l}0.036^{* *} \\
(0.018)\end{array}$ \\
\hline Decile & & $\begin{array}{c}-0.038^{* *} \\
(0.016)\end{array}$ & & $\begin{array}{c}-0.0056^{* *} \\
(0.0023)\end{array}$ \\
\hline Age & & $\begin{array}{l}0.012 * * * \\
(0.0024)\end{array}$ & & $\begin{array}{c}0.0018^{* * *} \\
(0.00036)\end{array}$ \\
\hline Female & & $\begin{array}{c}0.076 \\
(0.056)\end{array}$ & & $\begin{array}{c}0.015^{*} \\
(0.0083)\end{array}$ \\
\hline Education & & $\begin{array}{c}-0.14 * * * \\
(0.041)\end{array}$ & & $\begin{array}{c}-0.018 * * * \\
(0.0061)\end{array}$ \\
\hline Unemployed & & $\begin{array}{l}-0.15^{* *} \\
(0.064)\end{array}$ & & $\begin{array}{l}-0.018^{*} \\
(0.0094)\end{array}$ \\
\hline Constant & $\begin{array}{l}1.55^{* * *} \\
(0.061) \\
\end{array}$ & $\begin{array}{c}1.61^{* * *} \\
(0.19) \\
\end{array}$ & $\begin{array}{l}0.28^{* * *} \\
(0.0090) \\
\end{array}$ & $\begin{array}{l}0.28 * * * \\
(0.028) \\
\end{array}$ \\
\hline $\begin{array}{l}N \\
R^{2}\end{array}$ & $\begin{array}{l}1018 \\
0.015\end{array}$ & $\begin{array}{l}1008 \\
0.070\end{array}$ & $\begin{array}{l}1018 \\
0.007\end{array}$ & $\begin{array}{l}1008 \\
0.057\end{array}$ \\
\hline
\end{tabular}

Standard errors in parentheses

${ }^{*} p<0.10,{ }^{* *} p<0.05,{ }^{* * *} p<0.01$ 
Table 6: Information Effects Conditioning on Priors of Being Rich

\begin{tabular}{|c|c|c|c|c|}
\hline & $\begin{array}{c}(1) \\
\text { logratio }\end{array}$ & $\begin{array}{c}(2) \\
\text { logratio }\end{array}$ & $\begin{array}{c}\text { (3) } \\
\text { concentration }\end{array}$ & $\begin{array}{c}(4) \\
\text { concentration }\end{array}$ \\
\hline Info treatment & $\begin{array}{l}-0.052 \\
(0.058)\end{array}$ & $\begin{array}{l}-0.047 \\
(0.058)\end{array}$ & $\begin{array}{c}-0.010 \\
(0.0087)\end{array}$ & $\begin{array}{l}-0.0099 \\
(0.0087)\end{array}$ \\
\hline Richer & $\begin{array}{l}-0.12 \\
(0.073)\end{array}$ & $\begin{array}{c}-0.012 \\
(0.089)\end{array}$ & $\begin{array}{l}-0.019 * \\
(0.011)\end{array}$ & $\begin{array}{l}-0.0030 \\
(0.013)\end{array}$ \\
\hline Learn richer & $\begin{array}{l}-0.019 \\
(0.091)\end{array}$ & $\begin{array}{l}-0.0095 \\
(0.091)\end{array}$ & $\begin{array}{l}0.0040 \\
(0.014)\end{array}$ & $\begin{array}{l}0.0055 \\
(0.014)\end{array}$ \\
\hline Decile & & $\begin{array}{l}-0.022 * \\
(0.013)\end{array}$ & & $\begin{array}{l}-0.0037 * \\
(0.0020)\end{array}$ \\
\hline Age & & $\begin{array}{c}0.0079 * * * \\
(0.0019)\end{array}$ & & $\begin{array}{l}0.0012 * * * \\
(0.00028)\end{array}$ \\
\hline Female & & $\begin{array}{l}0.12 * * * \\
(0.044)\end{array}$ & & $\begin{array}{l}0.022 * * * \\
(0.0067)\end{array}$ \\
\hline Education & & $\begin{array}{c}-0.032 \\
(0.037)\end{array}$ & & $\begin{array}{l}-0.0040 \\
(0.0055)\end{array}$ \\
\hline Unemployed & & $\begin{array}{l}0.13 * * \\
(0.062)\end{array}$ & & $\begin{array}{c}0.0098 \\
(0.0093)\end{array}$ \\
\hline Constant & $\begin{array}{l}1.60 * * * \\
(0.047)\end{array}$ & $\begin{array}{c}1.37 * * * \\
(0.14)\end{array}$ & $\begin{array}{l}0.29 * * * \\
(0.0070)\end{array}$ & $\begin{array}{l}0.26^{* * *} \\
(0.021)\end{array}$ \\
\hline $\begin{array}{l}N \\
R^{2}\end{array}$ & $\begin{array}{l}1516 \\
0.007\end{array}$ & $\begin{array}{l}1509 \\
0.029\end{array}$ & $\begin{array}{l}1516 \\
0.005\end{array}$ & $\begin{array}{l}1509 \\
0.026\end{array}$ \\
\hline
\end{tabular}

Standard errors in parentheses

${ }^{*} p<0.10,{ }^{* *} p<0.05,{ }^{* * *} p<0.01$

We now turn to test hypothesis 4 , which specifies a specific relationship between the magnitude of learning and resulting preferences. We estimate OLS models as in the previous tables in which the coefficient of interest is now an interaction term between information treatment assignment and the variable magnitude, which is simply the difference between one's actual income decile and perceived decile. The magnitude variable ranges from -9 to 9, where higher values indicate a higher difference between the individual's actual income and perceived income. Therefore this interaction term, which we call amount learned, indicates the number of deciles the person learns that she is poorer or richer, relative to her prior. If there is a magnitude of learning effect, then the interaction term should be negative, as individuals who learn they are 
richer should be less progressive, as higher values of the difference variable mean the person is relatively richer than thought. We present these results in Table 7. As in previous tables, the first two columns estimate the conditional information impact on preferred log ratios; the latter two columns do so for the concentration coefficient. We find little confirmation of magnitude effects of learning, as the interaction term of interest remains substantively small and imprecisely estimated throughout all specifications. This means that to the extent there are information effects, they do not seem to be increasing in the amount of information the individual receives. 
Table 7: Effect of Magnitude of Learning on Progressivity Preferences

\begin{tabular}{|c|c|c|c|c|}
\hline & $\begin{array}{c}\text { (1) } \\
\text { Log ratio }\end{array}$ & $\begin{array}{c}(2) \\
\text { Log ratio }\end{array}$ & $\begin{array}{c}\text { (3) } \\
\text { Concentration }\end{array}$ & $\begin{array}{c}(4) \\
\text { Concentration }\end{array}$ \\
\hline Info treatment & $\begin{array}{l}0.0059 \\
(0.039)\end{array}$ & $\begin{array}{l}0.0095 \\
(0.038)\end{array}$ & $\begin{array}{l}0.00093 \\
(0.0057)\end{array}$ & $\begin{array}{c}0.0013 \\
(0.0057)\end{array}$ \\
\hline Magnitude & $\begin{array}{c}-0.024^{* *} \\
(0.010)\end{array}$ & $\begin{array}{c}-0.00090 \\
(0.013)\end{array}$ & $\begin{array}{c}-0.0031^{* *} \\
(0.0015)\end{array}$ & $\begin{array}{l}0.00041 \\
(0.0019)\end{array}$ \\
\hline Amount learned & $\begin{array}{r}-0.0067 \\
(0.013)\end{array}$ & $\begin{array}{l}-0.0035 \\
(0.013)\end{array}$ & $\begin{array}{l}0.00051 \\
(0.0019)\end{array}$ & $\begin{array}{l}0.00098 \\
(0.0019)\end{array}$ \\
\hline Correct & $\begin{array}{l}-0.078 \\
(0.085)\end{array}$ & $\begin{array}{l}-0.068 \\
(0.084)\end{array}$ & $\begin{array}{l}-0.011 \\
(0.013)\end{array}$ & $\begin{array}{l}-0.0092 \\
(0.013)\end{array}$ \\
\hline Learn correct & $\begin{array}{l}0.081 \\
(0.10)\end{array}$ & $\begin{array}{l}0.065 \\
(0.10)\end{array}$ & $\begin{array}{c}0.010 \\
(0.015)\end{array}$ & $\begin{array}{l}0.0074 \\
(0.015)\end{array}$ \\
\hline Decile & & $\begin{array}{c}-0.030 * * * \\
(0.011)\end{array}$ & & $\begin{array}{c}-0.0047 * * * \\
(0.0016)\end{array}$ \\
\hline Age & & $\begin{array}{c}0.0096 * * * \\
(0.0015)\end{array}$ & & $\begin{array}{l}0.0014 * * * \\
(0.00022)\end{array}$ \\
\hline Female & & $\begin{array}{c}0.10^{* * *} \\
(0.035)\end{array}$ & & $\begin{array}{l}0.020^{* * *} \\
(0.0052)\end{array}$ \\
\hline Education & & $\begin{array}{c}-0.083^{* * *} \\
(0.027)\end{array}$ & & $\begin{array}{c}-0.011^{* * *} \\
(0.0041)\end{array}$ \\
\hline Unemployed & & $\begin{array}{l}0.00030 \\
(0.044)\end{array}$ & & $\begin{array}{l}-0.0034 \\
(0.0066)\end{array}$ \\
\hline Constant & $\begin{array}{l}1.55^{* * *} \\
(0.031)\end{array}$ & $\begin{array}{c}1.48^{* * *} \\
(0.11)\end{array}$ & $\begin{array}{l}0.28^{* * *} \\
(0.0046)\end{array}$ & $\begin{array}{c}0.27 * * * \\
(0.017)\end{array}$ \\
\hline $\begin{array}{l}N \\
R^{2} \\
\end{array}$ & $\begin{array}{l}2534 \\
0.009 \\
\end{array}$ & $\begin{array}{l}2517 \\
0.037\end{array}$ & $\begin{array}{l}2534 \\
0.004 \\
\end{array}$ & $\begin{array}{l}2517 \\
0.032\end{array}$ \\
\hline
\end{tabular}

Standard errors in parentheses

${ }^{*} p<0.10,{ }^{* *} p<0.05,{ }^{* * *} p<0.01$

Finally, we test hypotheses 5a-5b, which are about the final income position that a respondent learns she is in. We can evaluate the impact of this information on individuals who learn they are poor or rich (which quintile they are in), compared to individuals who are similarly mistaken but were not told their real position. To test hypothesis 5, we examine the impact of learning that one is in a certain income category, compared to those who are similarly mistaken and are in the same income category, but do not learn. Simply put, does learning that one is in 
the poorest quintile matter versus learning that one is in the richest? Figure 4 displays these effects regarding preferences over tax ratios by quintile, comparing those untreated versus treated. From the figure we observe that only individuals who learn they are in the poorest quintile become more progressive when they learn they are in the bottom end of the income distribution.

Figure 4. Information effects by income quintile.

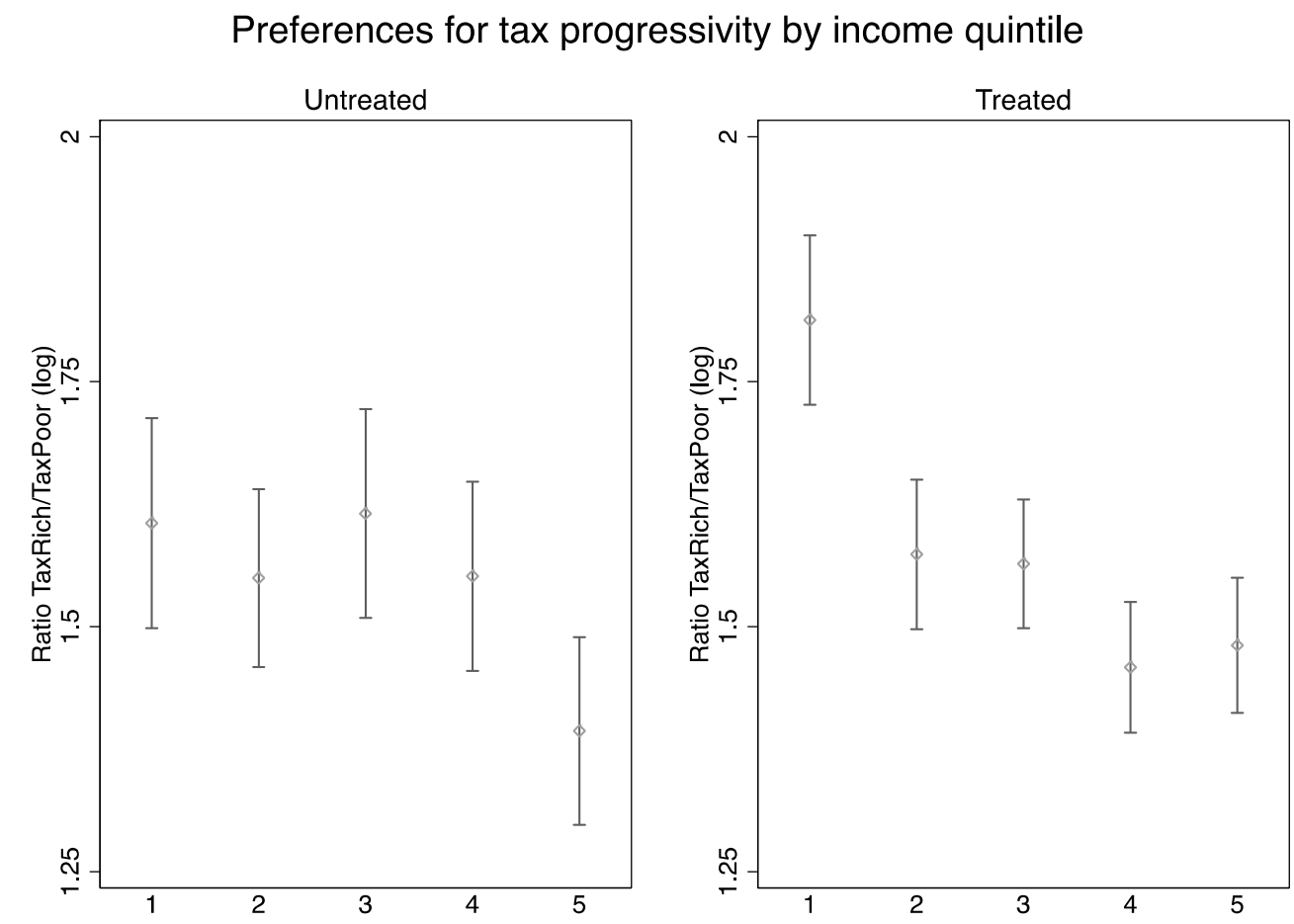

Tables 8 and 9 display the estimation results where we test the information treatment on the progressivity preferences for people who learn they are in the first, second, third, fourth, or fifth income quintiles. Table 8 displays the impact of the information treatment on preferences measured by the log ratio; Table 9 does so for the Kakwani concentration coefficient. Both results show that it is indeed individuals who learn that they are in the bottom quintile who become markedly more progressive, by both measures. This is consistent with H5a. However, we do not find similar effects for the second quintile. While the estimation model controlling for 
standard demographic covariates explains relatively little of the variation (roughly .05 to .06 across all quintiles), for the bottom quintile, the impact of learning that one is in the bottom quintile is by far the largest coefficient and most precisely estimated. The magnitude of this information effect in this income quintile is substantively large; the effect for the logged ratio of richest to poorest is equivalent to roughly one-quarter of a standard deviation in the distribution. Contra H5b, we find a positive effect for the treatment on individuals who learn they are in the top quintile (the treatment coefficient is surprisingly positive though imprecisely estimated). ${ }^{50}$

${ }^{50}$ This finding could be consistent with some models where individuals exhibit concerns about fairness. 
Table 8: Effect of Information Treatment on Support for Rich/Poor Tax Ratio, by Income Quintile

\begin{tabular}{|c|c|c|c|c|c|}
\hline & Q1 & Q2 & Q3 & Q4 & Q5 \\
\hline Info treatment & $\begin{array}{c}0.16 * \\
(0.090)\end{array}$ & $\begin{array}{c}0.037 \\
(0.079)\end{array}$ & $\begin{array}{c}-0.044 \\
(0.076)\end{array}$ & $\begin{array}{c}-0.12 \\
(0.075)\end{array}$ & $\begin{array}{c}0.065 \\
(0.078)\end{array}$ \\
\hline Age & $\begin{array}{c}0.0097 * * * \\
(0.0037)\end{array}$ & $\begin{array}{c}0.0070 * * \\
(0.0033)\end{array}$ & $\begin{array}{c}0.0098 * * * \\
(0.0032)\end{array}$ & $\begin{array}{c}0.010^{* * * *} \\
(0.0033)\end{array}$ & $\begin{array}{c}0.011 * * * \\
(0.0031)\end{array}$ \\
\hline Female & $\begin{array}{c}-0.093 \\
(0.089)\end{array}$ & $\begin{array}{l}0.18 * * \\
(0.077)\end{array}$ & $\begin{array}{l}0.21^{* * *} \\
(0.073)\end{array}$ & $\begin{array}{c}0.11 \\
(0.075)\end{array}$ & $\begin{array}{c}0.084 \\
(0.077)\end{array}$ \\
\hline Education & $\begin{array}{l}-0.12 * * \\
(0.060)\end{array}$ & $\begin{array}{l}-0.13^{* *} \\
(0.056)\end{array}$ & $\begin{array}{l}-0.12 * * \\
(0.058)\end{array}$ & $\begin{array}{l}-0.022 \\
(0.064)\end{array}$ & $\begin{array}{c}0.025 \\
(0.071)\end{array}$ \\
\hline Unemployed & $\begin{array}{l}-0.0068 \\
(0.088)\end{array}$ & $\begin{array}{c}-0.11 \\
(0.086)\end{array}$ & $\begin{array}{l}0.0094 \\
(0.090)\end{array}$ & $\begin{array}{c}0.14 \\
(0.13)\end{array}$ & $\begin{array}{c}-0.0021 \\
(0.14)\end{array}$ \\
\hline Constant & $\begin{array}{c}1.58 * * * \\
(0.24)\end{array}$ & $\begin{array}{c}1.52 * * * \\
(0.22)\end{array}$ & $\begin{array}{c}1.37 * * * \\
(0.22)\end{array}$ & $\begin{array}{c}1.14 * * * \\
(0.24)\end{array}$ & $\begin{array}{c}0.84^{* * *} \\
(0.26)\end{array}$ \\
\hline $\begin{array}{l}N \\
R^{2}\end{array}$ & $\begin{array}{c}452 \\
0.043\end{array}$ & $\begin{array}{c}474 \\
0.038\end{array}$ & $\begin{array}{c}534 \\
0.039\end{array}$ & $\begin{array}{c}539 \\
0.026\end{array}$ & $\begin{array}{c}516 \\
0.024\end{array}$ \\
\hline
\end{tabular}

Standard errors in parentheses

${ }^{*} p<0.10,{ }^{* *} p<0.05, * * * p<0.01$ 
Table 9: Effect of Information Treatment on Kakwani Concentration Coefficient, by Income Quintile

\begin{tabular}{|c|c|c|c|c|c|}
\hline & Q1 & Q2 & Q3 & Q4 & Q5 \\
\hline Info treatment & $\begin{array}{l}0.022 * \\
(0.012)\end{array}$ & $\begin{array}{l}-0.0024 \\
(0.012)\end{array}$ & $\begin{array}{c}-0.012 \\
(0.012)\end{array}$ & $\begin{array}{c}-0.012 \\
(0.012)\end{array}$ & $\begin{array}{c}0.014 \\
(0.012)\end{array}$ \\
\hline Age & $\begin{array}{c}0.0013^{* * *} \\
(0.00051)\end{array}$ & $\begin{array}{l}0.0011^{* *} \\
(0.00048)\end{array}$ & $\begin{array}{l}0.0013^{* *} \\
(0.00050)\end{array}$ & $\begin{array}{c}0.0016 * * * \\
(0.00051)\end{array}$ & $\begin{array}{c}0.0016^{* * *} \\
(0.00047)\end{array}$ \\
\hline Female & $\begin{array}{l}-0.0087 \\
(0.012)\end{array}$ & $\begin{array}{c}0.030 * * * \\
(0.011)\end{array}$ & $\begin{array}{c}0.030 * * * \\
(0.012)\end{array}$ & $\begin{array}{c}0.026 * * \\
(0.012)\end{array}$ & $\begin{array}{c}0.016 \\
(0.011)\end{array}$ \\
\hline Education & $\begin{array}{c}-0.012 \\
(0.0082)\end{array}$ & $\begin{array}{c}-0.016 * \\
(0.0083)\end{array}$ & $\begin{array}{c}-0.022 * * \\
(0.0092)\end{array}$ & $\begin{array}{l}-0.0059 \\
(0.0098)\end{array}$ & $\begin{array}{l}0.0055 \\
(0.011)\end{array}$ \\
\hline Unemployed & $\begin{array}{c}0.00079 \\
(0.012)\end{array}$ & $\begin{array}{c}-0.024^{*} \\
(0.013)\end{array}$ & $\begin{array}{c}0.00025 \\
(0.014)\end{array}$ & $\begin{array}{c}0.017 \\
(0.020)\end{array}$ & $\begin{array}{c}-0.00047 \\
(0.022)\end{array}$ \\
\hline Constant & $\begin{array}{c}0.27 * * * \\
(0.032)\end{array}$ & $\begin{array}{c}0.27 * * * \\
(0.032)\end{array}$ & $\begin{array}{c}0.28 * * * \\
(0.036)\end{array}$ & $\begin{array}{c}0.22^{* * *} \\
(0.037)\end{array}$ & $\begin{array}{c}0.16^{* * *} \\
(0.039)\end{array}$ \\
\hline $\begin{array}{l}N \\
R^{2}\end{array}$ & $\begin{array}{c}452 \\
0.036\end{array}$ & $\begin{array}{c}474 \\
0.040\end{array}$ & $\begin{array}{c}534 \\
0.035\end{array}$ & $\begin{array}{c}539 \\
0.028\end{array}$ & $\begin{array}{c}516 \\
0.026\end{array}$ \\
\hline
\end{tabular}

Standard errors in parentheses

$* p<0.10,{ }^{* *} p<0.05, * * * p<0.01$ 


\section{Section 5: Discussion}

In this study we examine the importance of information regarding one's relative income on tax progressivity preferences. We presented survey evidence from an experimental design that addresses important lacunae regarding accurate self-placement in the income distribution and preferences over tax policy, critical components to the theoretical and empirical discussion on redistribution preferences. To our knowledge this is the first study that experimentally manipulates provision of information on relative income in an advanced industrialized state in a survey context, and also measures tax preferences. We measured the degree to which individuals are misinformed about their own place in the income distribution. Then we tested whether the degree of misperception affects less explored outcomes such as the progressivity of the tax structure. Finally, we tested the impact of randomly informing some citizens of their correct place in the income distribution on tax preferences.

This design allowed us to attain multiple objectives. First, it tests a fundamental assumption of the main models of preferences for redistribution by specifying how much error there is in citizen views of their own place in the income scale, and whether such misperception is correlated with redistribution and tax preferences. ${ }^{51}$ Second, it allows us to assess the causal impact of correct information regarding placement in the income distribution on tax system preferences. Third, because we pose more specific outcome questions about preferred tax rates on different incomes, we are able to obtain more precise measures of progressivity views.

Overall, we find evidence of considerable error in citizen's awareness of their relative income position, and find that simple information about one's position in the distribution affects

\footnotetext{
${ }^{51}$ We focus on measuring perceptions of and information regarding where respondents are on an income scale, specifically ordering households and asking what percent are richer or poorer. We focus on relative position as opposed to differential shares of income because the former is easier for respondents to visualize and grasp, although future studies should explore the latter as well.
} 
tax preferences. We find that citizens can be quite misinformed about their relative income position. Although objective income is positively correlated with perceived relative income, there is quite a bit of error among citizens. Perhaps unsurprisingly, there is a clustering around the middle deciles, although in Spain this clustering is more around the middle-upper class deciles. We also find that female gender and labor market status are correlated with underestimating how relatively rich one is. Regarding preferences over progressivity, we find in the control group that perceived income is, as hypothesized, modestly negatively correlated with degree of progressivity (as measured by either highest to minimum tax rates, or using a standard tax progressivity concentration ratio). Richer citizens are more likely to support less progressive tax systems. Surprisingly, few other individual predictors explain such preferences.

We then specify a number of basic channels by which information about the individual's placement in the income distribution should affect her preferences, depending on the direction of bias correction, one's priors, the magnitude of learning, and the final income position revealed. We find that accurate information on one's relative place in the income distribution affects preferences for progressivity. If an individual learns that he is in the poorest quintile, he is likely to support higher tax progressivity. We also find that individuals who believe themselves to be poor and learn that they are poorer than what they though also become more also demand greater progressivity. In contrast, we do not find that such information effects exist for the rich or for those who learn they are richer. Our results reveal an interesting asymmetry in the effects of learning about the self-placement in the income distribution: it matters mainly for those with priors that they are poor and for those who learn they are poor. We suggest, but cannot confirm, that one reason why there are less systematic effects for individuals who learn they are richer and for individuals who learn they are rich is the presence of other concerns, such as inequality 
aversion or altruism, as theorized by others. ${ }^{52}$ There may be a compositional effect of individuals in these groups, where some individuals in response to such information become more altruistic, while others conform to more self-interested political economy models. Certainly more systematically testing these competing models is a path for future research.

Regardless of the causes of this asymmetrical information effect on progressivity preferences, the findings have important implications for the study of redistribution politics. They contribute to a better understanding of the role of political and economic knowledge (and asymmetries within both categories) on demands for progressivity. And correspondingly, they might contribute to our understanding of partisan strategies to address inequality-related issues in modern democracies, as parties might make different types of information more salient as electoral strategies.

The approach proposed here could be easily replicated in other OECD and developing countries. Evidence from Spain is relevant in that economic issues related to redistribution and progressivity have become more salient in recent years, but given evidence that the division in Spain over taxation and redistribution issues is lower than in other OECD states, and that such issues could be more persistently salient in other countries, one might find larger information effects in other countries, where class politics matters more. ${ }^{53}$ We focus on simple measurements of effective income tax rates for sensible income cut-off points to calculate measures of progressivity, but certainly measuring and explaining variation in other tax rates, such as consumption, estate, capital, or corporate taxes would be a useful way to extend this agenda. Regarding relevant extensions of information treatments, our current design allows us to

\footnotetext{
52 (Fehr \& Schmidt, 1999; Lu \& Scheve, 2014; Michelbach, Scott, Matland, \& Bornstein, 2003; Scott, Matland, Michelbach, \& Bornstein, 2001)

${ }^{53}$ On relative lack of division of taxation and redistribution issues see Fernández-Albertos \& Manzano (2012).
} 
compare individuals who are equivalently wrong about their perceived position, but then evaluate the impact of information on the sub-sample of wrong respondents. We hope this design and set of results contribute to the research agenda of understanding the impact of information on important redistribution preferences, and hopefully will contribute to more subtle theoretical models that will bringing in heterogeneity in individual-level information in explaining tax and redistribution preferences. 


\section{References}

Alesina, A., \& Angeletos, G.-M. (2005). Fairness and redistribution: US. The American Economic Review 95(4), 960-980.

Alesina, A., \& La Ferrara, E. (2005). Preferences for redistribution in the land of opportunities. Journal of Public Economics 89(1), 897-931.

Bartels, L. M. (2005). Homer gets a tax cut: Inequality and public policy in the American mind. Perspectives on Politics, 3(01), 15-31.

Bénabou, R., \& Ok, E. (2001). Social mobility and the demand for redistribution: the POUM hypothesis. Quarterly Journal of Economics 116(2), 447-487.

Bénabou, R., \& Tirole, J. (2006). Belief in a just world and redistributive politics. Quarterly Journal of Economics, 121(2), 699-746.

Beramendi, P., \& Rehm, P. (Forthcoming). Who gives, who gains? Progressivity and Preferences. Comparative Political Studies.

Boudreau, C., Lupia, A., Druckman, J., Green, D., Kuklinski, J., \& Lupia, A. (2011). Political knowledge. Cambridge handbook of experimental political science, 171-183.

Carpini, M. X. D., \& Keeter, S. (1996). What Americans know about politics and why it matters: Yale University Press.

Chetty, R., \& Saez, E. (2013). Teaching the tax code: Earnings responses to an experiment with EITC recipients. American Economic Journal: Applied Economics, 5(1), 1-31.

Costa Font, J., \& Gil, J. (2008). Exploring the pathways of inequality in health, access and financing in decentralised Spain. Documentos de trabajo (FEDEA)(13), 1-38.

Cruces, G., Truglia, R. P., \& Tetaz, M. (2013). Biased perceptions of income distribution and preferences for redistribution: Evidence from a survey experiment. Journal of Public Economics, 98(February), 100-112.

De Donder, P., \& Hindriks, J. (2003). The politics of progressive income taxation with incentive effects. Journal of Public Economics, 87(11), 2491-2505.

DiPrete, T. A. (2007). Is this a great country? Upward mobility and the chance for riches in contemporary America. Research in Social Stratification and Mobility, 25(1), 89-95.

Duflo, E., \& Saez, E. (2003). The role of information and social interactions in retirement plan decisions: Evidence from a randomized experiment. The Quarterly Journal of Economics, 118(3), 815-842.

Fehr, E., \& Schmidt, K. M. (1999). A theory of fairness, competition, and cooperation. Quarterly journal of Economics, 817-868.

Fernández-Albertos, J., \& Manzano, D. (2012). The Lack of Partisan Conflict over the Welfare State in Spain. South European Society and Politics, 17(3), 427-447.

Gallego, A. (2013). Attitudinal effects of income inequality: Cross-national and experimental evidence. Paper presented at the ECPR Joint Sessions Mainz, Germany.

Gingrich, J., \& Ansell, B. (2012). Preferences in Context Micro Preferences, Macro Contexts, and the Demand for Social Policy. Comparative Political Studies, 45(12), 1624-1654.

Heinemann, F., \& Hennighausen, T. (2010). Don't tax me? Determinants of individual attitudes toward progressive taxation. ZEW - Centre for European Economic Research Discussion Paper, (10-017).

Hindriks, J. (2001). Is there a demand for income tax progressivity? Economics Letters, 73(1), 43-50. 
Hurd, M. D. (2009). Subjective probabilities in household surveys. Annual Review of Economics, $1,543$.

Iversen, T., \& Soskice, D. (2001). An asset theory of social policy preferences. American Political Science Review, 95(4), 875-894.

Iyengar, S., \& Kinder, D. R. (1987). News that matters: Agenda-setting and priming in a television age: The University of Chicago Press.

Kakwani, N. C. (1977). Measurement of tax progressivity: an international comparison. The Economic Journal, 87(345), 71-80.

Klor, E. F. (2003). On the popular support for progressive taxation. Journal of Public Economic Theory, 5(4), 593-604.

Kuchler, F., \& Variyam, J. (2003). Mistakes were made: misperception as a barrier to reducing overweight. International journal of obesity, 27(7), 856-861.

Kuklinski, J. H., Quirk, P. J., Jerit, J., Schwieder, D., \& Rich, R. F. (2000). Misinformation and the currency of democratic citizenship. Journal of Politics, 62(3), 790-816.

Kuziemko, I., Norton, M. I., Saez, E., \& Stantcheva, S. (2013). How Elastic Are Preferences for Redistribution? Evidence from Randomized Survey Experiments: National Bureau of Economic Research.

Lenz, G. S. (2009). Learning and opinion change, not priming: Reconsidering the priming hypothesis. American Journal of Political Science, 53(4), 821-837.

Lu, X., \& Scheve, K. (2014). Inequity Aversion and the Mass Politics of Taxing the Rich in France and the United States.

Luskin, R. C., \& Bullock, J. G. (2011). 'Don’t Know’Means ‘Don’t Know’: DK Responses and the Public's Level of Political Knowledge. The Journal of Politics, 73(2), 547-557.

Manski, C. F. (2004). Measuring expectations. Econometrica, 72(5), 1329-1376.

Margalit, Y. (2013). Explaining social policy preferences: Evidence from the Great Recession. American Political Science Review, 107(01), 80-103.

Marhuenda, F., \& Ortuño-Ortín, I. (1995). Popular support for progressive taxation. Economics Letters, 48(3), 319-324.

Maximova, K., McGrath, J. J., Barnett, T., O'Loughlin, J., Paradis, G., \& Lambert, M. (2008). Do you see what I see? Weight status misperception and exposure to obesity among children and adolescents. International journal of obesity, 32(6), 1008-1015.

McCall, L. (2013). The undeserving rich : American beliefs about inequality, opportunity, and redistribution: Cambridge University Press.

McCall, L., \& Chin, F. (2013). Does Knowledge of Inequality Affect Beliefs about Inequality? Paper presented at the Midwest Political Science Association, Chicago, IL.

McCall, L., \& Kenworthy, L. (2009). Americans' social policy preferences in the era of rising inequality. Perspectives on Politics, 7(3), 459-484.

Meltzer, A. H., \& Richard, S. F. (1981). A rational theory of the size of government. The Journal of Political Economy, 89(5), 914-927.

Michelbach, P. A., Scott, J. T., Matland, R. E., \& Bornstein, B. H. (2003). Doing Rawls justice: An experimental study of income distribution norms. American Journal of Political Science, 47(3), 523-539.

Miller, J. M., \& Krosnick, J. A. (2000). News Media Impact on the Ingredients of Presidential Evaluations: Politically Knowledgeable Citizens Are Guided by a Trusted Source. American Journal of Political Science, 44(2), 301-315. 
Neckerman, K. M., \& Torche, F. (2007). Inequality: causes and consequences. Annu. Rev. Sociol., 33, 335-357.

Neuman, W. R. (1992). Common knowledge: News and the construction of political meaning: University of Chicago Press.

Norton, M. I., \& Ariely, D. (2011). Building a better America-One wealth quintile at a time. Perspectives on Psychological Science, 6(1), 9-12.

Osberg, L., \& Smeeding, T. (2006). "Fair” inequality? Attitudes toward pay differentials: the United States in comparative perspective. American Sociological Review, 71(3), 450-473.

Page, B. I., \& Shapiro, R. Y. (2010). The rational public: Fifty years of trends in Americans' policy preferences: University of Chicago Press.

Piketty, T. (2014). Capital in the twenty-first century: Belknap Press.

Prasad, M., \& Deng, Y. (2009). Taxation and the worlds of welfare. Socio-Economic Review, 7(3), 431-457.

Prior, M., \& Lupia, A. (2008). Money, time, and political knowledge: Distinguishing quick recall and political learning skills. American Journal of Political Science, 52(1), 169-183.

Rehm, P. (2009). Risks and Redistribution: An Individual-Level Analysis. Comparative Political Studies, 42(7), 855-881.

Rehm, P. (2011). Social Policy by Popular Demand. World Politics, 63(2), 271-299.

Rehm, P., Hacker, J. S., \& Schlesinger, M. (2012). Insecure Alliances: Risk, Inequality, and Support for the Welfare State. American Political Science Review, 106(2), 386-406.

Reimers, S. (2009). A paycheck half-empty or half-full? Framing, fairness and progressive taxation.

Roberts, M. L., Hite, P. A., \& Bradley, C. F. (1994). Understanding attitudes toward progressive taxation. Public Opinion Quarterly, 58(2), 165-190.

Roemer, J. E. (1999). The democratic political economy of progressive income taxation. Econometrica, 67(1), 1-19.

Romer, T. (1975). Individual welfare, majority voting, and the properties of a linear income tax. Journal of Public Economics, 4(2), 163-185.

Rueda, D. (2005). Insider-outsider politics in industrialized democracies: the challenge to social democratic parties. American Political Science Review, 99(1), 61-74.

Scheve, K., \& Stasavage, D. (2010). The Conscription of Wealth: Mass Warfare and the Demand for Progressive Taxation. International Organization, 64(4), 529-562.

Scott, J. T., Matland, R. E., Michelbach, P. A., \& Bornstein, B. H. (2001). Just deserts: an experimental study of distributive justice norms. American Journal of Political Science, 749-767.

Sides, J. (2011). Stories, Science, and Public Opinion about the Estate Tax. Retrieved from http://home.gwu.edu/ jsides/estatetax.pdf

Slemrod, J. (2006). The role of misconceptions in support for regressive tax reform. National Tax Journal, 59(1), 57-75.

Snyder, J. M., \& Kramer, G. H. (1988). Fairness, self-interest, and the politics of the progressive income tax. Journal of Public Economics, 36(2), 197-230.

Stroup, M. D. (2005). An index for measuring tax progressivity. Economics Letters, 86(2), 205213.

Truesdale, K. P., \& Stevens, J. (2008). Do the obese know they are obese? North Carolina medical journal, 69(3), 188.

Urban, I. (2009). Kakwani decomposition of redistributive effect: Origins, critics and upgrades. 
Van der Brug, W., Semetko, H. A., \& Valkenburg, P. M. (2007). Media priming in a multi-party context: A controlled naturalistic study in political communication. Political Behavior, 29(1), 115-141. 


\section{Appendix A}

Descriptive Statistics Table

$\begin{array}{lcccc}\begin{array}{l}\text { Variable } \\ \text { Log (ratio tax rich / } \\ \text { tax poor) }\end{array} & \text { Mean } & \text { S.D. } & \text { Min } & \text { Max } \\ \begin{array}{l}\text { Kakwani } \\ \text { Concentration }\end{array} & 1.59 & 0.88 & 0 & 4.61 \\ \text { coefficient } & 0.29 & 0.13 & 0 & .75 \\ \begin{array}{l}\text { Decile } \\ \text { Perceived decile }\end{array} & 5.73 & 2.77 & 1.0 & 10 \\ \text { Ideology } & 5.79 & 1.80 & 1.0 & 10 \\ \text { Age } & 4.32 & 2.19 & 1.0 & 10 \\ \text { Unemployed } & 40.48 & 12.17 & 18.0 & 64 \\ \text { Household size } & 0.19 & 0.40 & 0.0 & 1 \\ \text { Education } & 3.04 & 1.16 & 1.0 & 8 \\ & 2.42 & 0.67 & 1.0 & 3\end{array}$




\section{Appendix B: Supplemental Tables}

Table B. Explaining Error in Perceived Income

(1)

(2)

\begin{tabular}{|c|c|c|}
\hline Income decile & $\begin{array}{c}-0.050^{* * *} \\
(0.012)\end{array}$ & $\begin{array}{c}-0.050^{* * *} \\
(0.012)\end{array}$ \\
\hline Ideology & $\begin{array}{r}-0.0055 \\
(0.013)\end{array}$ & $\begin{array}{l}-0.0053 \\
(0.013)\end{array}$ \\
\hline Age & $\begin{array}{c}-0.0083^{* * *} \\
(0.0025)\end{array}$ & $\begin{array}{c}-0.0084^{* * *} \\
(0.0025)\end{array}$ \\
\hline Female & $\begin{array}{c}0.18^{* * *} \\
(0.059)\end{array}$ & $\begin{array}{c}0.18^{* * * *} \\
(0.059)\end{array}$ \\
\hline Unemployed & $\begin{array}{l}0.26^{* * *} \\
(0.076)\end{array}$ & $\begin{array}{c}0.26^{* * *} \\
(0.076)\end{array}$ \\
\hline Household size & $\begin{array}{c}0.033 \\
(0.025)\end{array}$ & $\begin{array}{c}0.034 \\
(0.025)\end{array}$ \\
\hline Education & $\begin{array}{c}-0.18^{* * *} \\
(0.046)\end{array}$ & $\begin{array}{l}-0.18^{* * *} \\
(0.046)\end{array}$ \\
\hline Treatment 2 & & $\begin{array}{c}0.13 \\
(0.081)\end{array}$ \\
\hline Treatment 3 & & $\begin{array}{l}0.0029 \\
(0.071)\end{array}$ \\
\hline Constant & $\begin{array}{l}3.02^{* * *} \\
(0.20)\end{array}$ & $\begin{array}{l}2.99^{* * *} \\
(0.20)\end{array}$ \\
\hline $\begin{array}{l}N \\
R^{2}\end{array}$ & $\begin{array}{c}3378 \\
0.033\end{array}$ & $\begin{array}{r}3378 \\
0 \quad 034\end{array}$ \\
\hline
\end{tabular}

Standard errors in parentheses

${ }^{*} p<0.10,{ }^{* *} p<0.05,{ }^{* * *} p<0.01$ 